\title{
Measurement of cellular $\beta$-site of APP cleaving enzyme 1 activity and its modulation in neuronal assay systems
}

\author{
Christiane Volbracht ${ }^{\mathrm{a}, 1}$, Stephan Penzkofer ${ }^{\mathrm{b}, *, 1}$, David Mansson ${ }^{\mathrm{a}}$, Kenneth Vielsted Christensen ${ }^{\mathrm{a}}$, \\ Karina Fog ${ }^{a}$, Stefan Schildknecht ${ }^{\mathrm{b}}$, Marcel Leist ${ }^{\mathrm{b}, 1}$, Jacob Nielsen ${ }^{\mathrm{a}, 1,2}$ \\ ${ }^{a} H$. Lundbeck A/S, 2500 Valby, Denmark \\ ${ }^{\mathrm{b}}$ Department of Biology, University of Konstanz, D-78457 Konstanz, Germany
}

\section{A R T I C L E I N F O}

\section{Article history:}

Received 4 November 2008

Available online 15 January 2009

\section{Keywords:}

BACE1

Amyloid- $\beta$ peptide $(A \beta)$

APP

SEAP

CGC

HEK293

\begin{abstract}
A B S T R A C T
Amyloid- $\beta$ peptide (A $\beta$ ), a putatively causative agent of Alzheimer's disease (AD), is proteolytically derived from $\beta$-amyloid precursor protein (APP). Here we describe cellular assays to detect the activity of the key protease $\beta$-site of APP cleaving enzyme 1 (BACE1) based on an artificial reporter construct containing the BACE1 cleavage site of APP. These methods allow identification of inhibitors and indirect modulators of BACE1. In primary neuronal cultures transfected with human APP constructs (huAPP), $A \beta$ production was modified by BACE1 inhibitors similarly to the production of endogenous murine $A \beta$ in wild-type cells and to that of different transgenic neurons. To further improve the assay, we substituted the extracellular domain of APP by secreted alkaline phosphatase (SEAP). SEAP was easily quantified in the cell culture supernatants after cleavage of SEAP-APP by BACE1 or $\alpha$-secretases. To render the assay specific for BACE1, the $\alpha$-secretase cleavage site of SEAP-APP was eliminated either by site-directed mutagenesis or by substituting the transmembrane part of APP by the membrane domain of the erythropoietin receptor (EpoR). The pharmacology of these constructs was characterized in detail in HEK293 cells (human embryonic kidney cell line), and the SEAP-APP-EpoR construct was also introduced into primary murine neurons and there allowed specific measurement of BACE1 activity.
\end{abstract}

Alzheimer's disease $(A D)^{3}$ is the most common cause of dementia diagnosed in the elderly today and is now being recognized as one of the major public health problems in developed nations [1]. A histopathological hallmark of $\mathrm{AD}$ is amyloid plaques, composed mainly of the

* Corresponding author. Fax: +49 7531885039.

E-mail address: stephan.penzkofer@uni-konstanz.de (S. Penzkofer).

1 These authors contributed equally to this work.

${ }^{2}$ For material requests refer to J.N.:jcni@lundbeck.com

3 Abbreviations used: AD, Alzheimer's disease; A $\beta$, amyloid- $\beta$ peptide; APP, $\beta$ amyloid precursor protein; BACE1, $\beta$-site of APP cleaving enzyme 1; sAPP, soluble APP; CTF, C-terminal fragment; AICD, APP intracellular domain; swe, Swedish; IPAD, isophthalamide derivative; AQD, aminoquinazoline derivative; HEK, human embryonic kidney; DMEM, Dulbecco's modified Eagle's medium; CTX, cortical; NBM, Neurobasal medium; DIV, days in vitro; GFAP, glial fibrillary acidic protein; CGC, cerebellar granule cell; BME, basal medium with Earle's salts; FBS, fetal bovine serum; SEAP, secreted alkaline phosphatase; wt, wild type; EpoR, erythropoietin receptor; PCR, polymerase chain reaction; RT, reverse transcription; cDNA, complementary DNA; siRNA, small interfering RNA; GFP, green fluorescent protein; mRNA, messenge RNA; MTT, 3-(4,5-dimethylthiazole-2-yl)-2,5-diphenyltetrasodium bromide; pNPP, para-nitrophenylphosphate; ELISA, enzyme-linked immunosorbent assay; SDS-PAGE, sodium dodecyl sulfate-polyacrylamide gel electrophoresis; PVDF, polyvinylidene fluoride; PBS, phosphate-buffered saline; ECL, enhanced chemiluminescence; EDTA, ethylenediaminetetraacetic acid; EGTA, ethyleneglycoltetraacetic acid; PMSF, phenylmethylsulfonylfluoride; $\operatorname{Ig} G_{1}$, immunoglobulin $G 1$; HRP, horseradish peroxidase; CCD, charge-coupled device; HPLC, high-performance liquid chromatography. amyloid- $\beta$ peptide $(A \beta)$. The widely accepted "amyloid hypothesis" [2-4] considers $A \beta$ as the initiator of the pathological cascade that eventually leads to neuronal dysfunction and dementia. According to this hypothesis, $\mathrm{AD}$ results from a chronic imbalance between the production and disposal of $A \beta$. $A \beta$ is generated by sequential proteolytic cleavage of the type I membrane protein $\beta$-amyloid precursor protein (APP). The aspartyl protease $\beta$-site of APP cleaving enzyme 1 (BACE1) was identified as the so-called $\beta$-secretase [5-8] and produces a secreted $\mathrm{N}$ terminal (soluble APP $\beta$ [SAPP $\beta]$ ) and a membrane-anchored C-terminal fragment (CTF $\beta$ ). CTF $\beta$ is subsequently cleaved by a multiprotein complex termed $\gamma$-secretase to yield an APP intracellular domain (AICD) with signaling functions in the nucleus [9] as well as $A \beta_{1-40}$ and $A \beta_{1-42}$ (alternative cleavage sites). Formation of amyloidogenic $A \beta$ fragments can be prevented by the action of $\alpha$-secretase that acts between the potential $\beta$ - and $\gamma$-cleavage sites and results in the formation of the soluble sAPP $\alpha$ fragment $[10,11]$. Both $\beta$ - and $\gamma$-secretases are targets for potentially disease-modifying pharmacological intervention strategies in AD. Because $\gamma$-secretase inhibitors may be associated with side effects due to inhibited Notch signaling [12], there is currently particularly strong interest in BACE1 inhibitors. Efficacy and safety of such compounds are suggested by the phenotype of BACE1 knockout mice, which are healthy [13-15] except for high pup mortality [16] and hypomyelination in juvenile development $[17,18]$ 
and do not develop AD pathology when crossed with APP transgenic mice [19]. Although the crystal structure of BACE1 has been resolved [20-22] and the enzymatic mechanism is well characterized [22], developing clinically useful inhibitors of the enzyme has proven to be difficult. Reasons for this are the difficult molecular pharmacology of aspartate proteases, which also include renin and HIV protease $[23,24]$; the localization of the target behind the blood-brain barrier; and the complex cell biology of BACE1, which cycles between membrane and intracellular organelles [25], cleaves APP mainly in the early endosomal compartment, and has an acidic $\mathrm{pH}$ optimum [25-28]. The latter issue is responsible for the fact that cell-free enzymatic inhibition data of drug candidates do not always predict their activity in cellular systems. The situation is even more difficult in neurons, where different localizations of BACE1 and APP along the neurites make predictions on the effects of BACE1 inhibitors difficult [29,30]. Due to the problems with the design of inhibitors blocking the active site of BACE1, alternative approaches aim to modify cellular BACE1 activity. Change of localization, phosphorylation, or binding partners of BACE1 may have such effects. To explore this type of pharmacology, specific cellular BACE1 assays are urgently needed. Such cell models should be applicable for high-throughput applications, allow a fast and cost-efficient readout of $\beta$-secretase activity, and simulate the specific neuronal situation. These requirements are best met by a battery of different systems that were developed in the current study. The problem of a simple readout was addressed by converting BACE1 activity to the measurement of alkaline phosphatase. The specificity issue was addressed by new types of mutations introduced in the cleavage sequence of $\alpha$ - and $\gamma$-secretases. The issue of the neuronal environment was addressed by optimization of the expression of human APP in murine neurons. All assay variants were pharmacologically validated with highly specific inhibitors of $\beta$ - and $\gamma$-secretases.

\section{Materials and methods}

\section{Reagents}

All reagents and antibodies were purchased from Sigma-Aldrich (St. Louis, MO, USA) if not otherwise indicated. The BACE1 inhibitor IPAD (isophthalamide derivative) [31] (cat. no. 565788) was purchased as $\beta$-secretase inhibitor IV from Merck/Calbiochem (Darmstadt, Germany). AQD (aminoquinazoline derivative) [32] was synthesized following the schemes provided by Johnson \& Johnson (Beerse, Belgium). The $\gamma$-secretase inhibitors DAPT [33], GSI-18 [34], and GSI-19 [35] were purchased as $\gamma$-secretase inhibitors IX, XVIII, and XIX, respectively, from Merck/Calbiochem (cat. nos. 565770, 565779, and 565787, respectively). LY450139 [36] was synthesized following the schemes provided by Lilly (Indianapolis, IN, USA). The $\alpha$-secretase inhibitor GM6001 (cat. no. 364205) was purchased from Merck/Calbiochem.

\section{Animals}

Double-transgenic APPswe (Swedish)/PS1 $\Delta \mathrm{E} 9$ mice were originally obtained from David R. Borchelt (Johns Hopkins University School of Medicine) and bred at M\&B A/S (Ry, Denmark). APPswe/ PS1 $\triangle \mathrm{E} 9$ mice harbor a chimeric murine-human APP and a mutant of human preseniline 1 (PS1), both under control of the murine prion protein promoter [37]. The chimeric APP is based on the murine APP isoform with 695 amino acids, engineered to contain the human $A \beta$ and the Swedish mutation (KM595/596NL), whereas the human PS1 has deletion of exon 9 (PS1 $\triangle \mathrm{E} 9$ ) [38]. BALB/c mice were either purchased from Charles River Laboratories (Wilmington, MA, USA) or obtained from the animal house of the University of Konstanz. Handling of transgenic and wild-type mice was conducted by professional staff of the respective animal housing units according to national and European ethical and legal guidelines.

\section{Cell culture}

HEK293 cells (human embryonic kidney cell line) were cultured in Dulbecco's modified Eagle's medium (DMEM) supplemented with $5 \%$ heat-inactivated fetal calf serum, $100 \mathrm{U} / \mathrm{ml}$ penicillin, and $0.1 \mathrm{mg} / \mathrm{ml}$ streptomycin (Gibco BRL Invitrogen, Carlsbad, CA, USA).

Cortical (CTX) neurons were isolated from day 14 to 16 fetal APPswe/PS1 $\triangle \mathrm{E} 9$ mice as described previously [39]. Briefly, dissociated neurons were plated on $100 \mu \mathrm{g} / \mathrm{ml}$ poly-L-lysine-coated dishes at a density of approximately $2.5 \times 10^{5}$ cells $/ \mathrm{cm}^{2}$ (800,000 cells/ml, $100 \mu \mathrm{l} /$ well, 96 -well plate) and cultured in Neurobasal medium (NBM) supplemented with $2 \%$ B-27 without antioxidants, $0.5 \mathrm{mM}$ L-glutamine, $100 \mathrm{U} / \mathrm{ml}$ penicillin, and $0.1 \mathrm{mg} / \mathrm{ml}$ streptomycin (all solutions from Gibco BRL Invitrogen). Every third day, half of the medium was replaced. CTX neurons were usually used at 6 days in vitro (DIV) after complete medium change. The proportion of astrocytes in the cultures was less than $10 \%$, as assessed by staining for glial fibrillary acidic protein (GFAP).

Cerebellar granule cells (CGCs) were isolated from 7-day-old APPswe/PS1 $\triangle \mathrm{E} 9$ or BALB/c mice. Cerebelli were dissociated as described previously [40]. The cells were suspended in basal medium with Earle's salts (BME) supplemented with $10 \%$ fetal bovine serum (FBS), $20 \mathrm{mM} \mathrm{KCl}, 0.5 \mathrm{mM}$ glutamine, $100 \mathrm{U} / \mathrm{ml}$ penicillin, and $0.1 \mathrm{mg} / \mathrm{ml}$ streptomycin and were seeded on $100 \mu \mathrm{g} / \mathrm{ml}$ poly-L-lysine-coated dishes at a density of approximately $6 \times 10^{5}$ cells/ $\mathrm{cm}^{2}$ (1,900,000 cells/ml, $100 \mu \mathrm{l} /$ well, 96 -well plate). Then, $45 \mathrm{~min}$ after plating, medium was substituted by NBM supplemented with $2 \% \mathrm{~B} 27,20 \mathrm{mM} \mathrm{KCl}, 0.5 \mathrm{mM}$ glutamine, $100 \mathrm{U} / \mathrm{ml}$ penicillin, and $0.1 \mathrm{mg} / \mathrm{ml}$ streptomycin (all solutions from Gibco BRL Invitrogen). Half of the medium was replaced every third day. CGCs were usually used at 3 DIV after complete medium change. The proportion of astrocytes in the cultures was less than $5 \%$, as assessed by staining for GFAP.

\section{DNA constructs}

The APP constructs used in this study were generated in a pcDNA3.1 vector backbone. The secreted alkaline phosphatase (SEAP) sequence substituted the $\mathrm{N}$-terminal domain up to and including Leu583 of APPswe or APPwt (wild type). In the APPerythropoietin receptor (EpoR) constructs, the C-terminal region downstream of Gly605 of APPswe (KM595/596NL) or APPwt was replaced by the EpoR transmembrane domain.

\section{Cloning of SEAP-APPswe and SEAP-APPwt}

SEAP-APPswe was cloned by fusing SEAP with an overlap polymerase chain reaction (PCR) approach to human APPswe, 13 amino acids $N$ terminal of its $\beta$-cleavage site. Full-length SEAP and truncated human APPswe were PCR amplified in two separate PCR reactions using either pSEAPbasic (Clontech, Palo Alto, CA, USA) or an in-house cloned human APPswe in the pcDNA3.1 vector. The SEAP fragment was amplified with the primers $5^{\prime}$-GGTACC GAGCTCTTACGCGT-3' and 5'-CTCCTCCGTCTTGATATTTGTCTGCTC GAAGCGGCC- $3^{\prime}$. The APPswe fragment was amplified with the primers 5'-GGCCGCTTCGAGCAGACAAATATCAAGACGGAGGAG-3' and 5'-TGAACTCCCACGTTCACATG-3'. The purified PCR products were used as templates in a third PCR reaction with the primers 5'-GGTACCGAGCTCTTACGCGT- ${ }^{\prime}$ and 5'-TGAACTCCCACGTTCACATG-3'. Subsequently, the SEAP-APPswe PCR product was NheI and ClaI digested and ligated into an NheI and ClaI digested pcDNA3.1 construct expressing human APPswe. For generating SEAP-APPwt, the same cloning approach was used by fusing the human APPwt to SEAP. 
To introduce the human APP-ABK16V (K612V in APP695 nomenclature) and APP-ABK16E (K612E in APP695 nomenclature) $\alpha$-mutations into SEAP-APPwt, DpnI-mediated site-directed mutagenesis was applied [41]. Human APPwt was used as template in a PCR reaction with sense and antisense primers harboring the mutations. Sense primers for $A \beta K 16 \mathrm{~V}$ and $\mathrm{A} \beta \mathrm{K} 16 \mathrm{E}$ were $5^{\prime}-$ GAAGTTCATCATCAAGTATTGGTGTTCTTTGCA- $3^{\prime}$ and 5'-TGAAGTTC ATCATCAAGAATTGGTGTTCTTTGCAG-3', respectively. Antisense primers for $\mathrm{A} \beta \mathrm{K} 16 \mathrm{~V}$ and $\mathrm{A} \beta \mathrm{K} 16 \mathrm{E}$ were $5^{\prime}$-TGCAAAGAACACCAATA CTTGATGATGAACTTC- $3^{\prime}$ and 5'-CTGCAAAGAACACCAATTCTTGATG ATGAACTTCA-3', respectively. Subsequently, the methylated parental plasmid DNA was degraded by digestion with DpnI. Finally, an aliquot of the digested PCR reaction was transformed into the highly competent Escherichia coli DH5 $\alpha$ strain for minipreparation of mutant plasmid DNA.

\section{Cloning of SEAP-APPswe-EpoR}

SEAP-APPswe-EpoR and SEAP-APPwt-EpoR were cloned by an overlap PCR approach. Briefly, SEAP-APPswe truncated 9 amino acids downstream of the $\beta$-cleavage site was amplified from pSEAP-APPswe with the following primers: $5^{\prime}$-GCGCCTGCTGAG

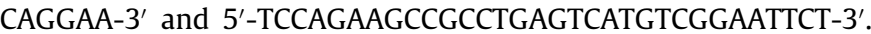
Then 52 amino acids covering parts of the extracellular, the transmembrane domain, and the intracellular domain of human EpoR (amino acids 231-282, Acc. No. NM_000121.2) were reverse transcription (RT)-PCR amplified from human polyA+ RNA with 5'ACATGACTCAGGCGGCTTCTGGAGCGCCT- $3^{\prime}$ and $5^{\prime}$-GGAAGCTCTA GATCTTCTGCTTCAGAGCCC- 3 '. The purified PCR products were used as templates in a third PCR reaction with the primers $5^{\prime}$ GCGCCTGCTGAGCAGGAA- $3^{\prime}$ and 5'-GGAAGCTCTAGATCTTCTGCTT CAGAGCCC-3'. Subsequently, the PCR product was digested with Sac2 and Not1 and the 834-bp fragment was ligated into the above-mentioned pSEAP-APPswe. All constructs were sequence verified.

The BACE1 plasmid was generated by insertion of human BACE1 complementary DNA (cDNA) into a pCI-IRES-Hyg2 backbone.

\section{Small interfering RNA}

Small interfering RNA (siRNA) was purchased from Applied Biosystems/Ambion (Naerum, Denmark) or from MWG (Ebersberg, Germany). The following sequences were chosen as targets for SiRNA:

- 5'-GCTCTTTTTAACACTCTTA-3' from murine BACE1 (NM_011792); - 5'-GCTTTGTGGAGATGGTGGA-3' from human BACE1 (NM_ 012104);

- 5'-TGAAGTGAATCTGGATGCA-3', based on human APP (NM_ 201414) with Swedish mutation;

- 5'-GCCAAGAACCTCATCATCT-3' from human SEAP (NM_ 031313);

- 5'-GCAAGCTGACCCTGAAGTT-3' from jellyfish green fluorescent protein (GFP) (Clontech C1eGFP).

\section{Determination of messenger RNA knockdown}

siRNA-induced knockdown of a particular messenger RNA (mRNA) was controlled by comparison of the mRNA level in cells transfected with siRNA targeting this mRNA with the level in cells transfected with negative control siRNA (Applied Biosystems/ Ambion). mRNA was isolated using an RNA extraction kit from Qiagen (Hilden, Germany) and transcribed into cDNA, and finally the level of cDNA was scaled with semiquantitative RT-PCR and GAPDH, HPRT-1, or S18 as internal controls.

\section{Transfections}

Transfections were conducted either using Lipofectamine 2000 (Invitrogen, Carlsbad, CA, USA) and following the manufacturer's instructions or with the Amaxa electroporation method using Amaxa Nucleofector II (Amaxa, Köln, Germany). HEK293 cells were transfected using Amaxa Nucleofector II with program Q-001, with a single cell suspension (from trypsinization) of $10^{6}$ cells in $100 \mu \mathrm{l}$ Opti-MEM, and mixed with $5 \mu \mathrm{g}$ of plasmid with or without $4 \mu \mathrm{M}$ siRNA. After transfection, cells were seeded at a density of $3 \times 10^{5}$ $\mathrm{cm}^{2}$ in 96 -well plates.

Using Lipofectamine 2000, $3 \times 10^{6}$ HEK293 cells were seeded in T75 flasks overnight before transfection. Then $10 \mu \mathrm{g}$ DNA of SEAPAPPwt-A $3 K 16 \mathrm{~V}$ or $5 \mu \mathrm{g}$ of BACE1 constructs was transfected (or cotransfected in a $1: 1$ ratio). Then, $24 \mathrm{~h}$ after transfection, cells were trypsinized and seeded at a density of $3 \times 10^{5} / \mathrm{cm}^{2}$ in 96 -well plates.

For transfection of CGCs with Amaxa Nucleofector II, $6 \times 10^{6}$ cells in a single cell suspension obtained directly after cell isolation were nucleofected using $100 \mu \mathrm{l}$ of the mouse neuron nucleofection kit (Amaxa) and program G-13. Then $10 \mu \mathrm{g}$ DNA of APPswe or APPwt and $2 \mu \mathrm{g}$ of pEGFP-C3 constructs was transfected either separately or in cotransfection with or without siRNA. After transfection, CGCs were seeded at a density of $3 \times 10^{6} / \mathrm{cm}^{2}$ on $100 \mu \mathrm{g} / \mathrm{ml}$ poly-L-lysine-coated 96-well plates. Transfection efficiency for siRNA was determined with fluorescence-labeled scrambled siRNA (2-20 $\mu \mathrm{M}$, Silencer Cy3-labeled negative control from Ambion, Hopkinton, MA, USA) after $48 \mathrm{~h}$.

\section{Cell viability measurements}

For detection of cell viability, the percentage of viable cells was quantified by their capacity to reduce 3-(4,5-dimethyl-2-thiazolyl)-2,5-diphenyl-2H-tetrazolium bromide (MTT) after incubation with $0.5 \mathrm{mg} / \mathrm{ml}$ MTT for $60 \mathrm{~min}$ [42]. Viability was routinely measured after all pharmacological experiments for all conditions and revealed significant effects on the viability of CGC at $\geqslant 10 \mu \mathrm{M}$ IPAD or $\geqslant 2 \mu \mathrm{M}$ AQD. HEK293 cells were unaffected by the inhibitors.

\section{SEAP measurement}

The SEAP assay is based on the hydrolytic activity of the reporter enzyme SEAP [43]. The colorless substrate para-nitrophenylphosphate (pNPP, cat. no. N2765, Sigma) is hydrolyzed by SEAP to produce phosphate and the yellow chromophore para-nitrophenolate (King-Armstrong method) [44]. The absorption change was measured for at least $10 \mathrm{~min}$ at $405 \mathrm{~nm}$ at ambient temperature. For each measurement, $10 \mu \mathrm{l}$ of sample was added to $100 \mu \mathrm{l}$ of sample buffer $(2.4 \mathrm{mM}$ pNPP [ $1 \mathrm{mg} / \mathrm{ml}], 0.1 \mathrm{M}$ glycine, $1 \mathrm{mM}$ $\mathrm{MgCl}_{2}$, and $1 \mathrm{mM} \mathrm{ZnCl}$ at $\left.\mathrm{pH} 10.4\right)$.

\section{$A \beta_{1-40} / A \beta_{1-42}$ quantification}

$A \beta_{1-40}$ and $A \beta_{1-42}$ were determined with sandwich enzymelinked immunosorbent assay (ELISA) kits (BioSource, Camarillo, CA, USA, and Wako Pure Chemical Industries, Osaka, Japan) according to the manufacturers' instructions.

\section{sAPP $\beta$ quantification}

sAPP $\beta$ was determined with a sandwich ELISA kit from IBL (Hamburg, Germany). 
Western blot analysis

APP and APP cleavage products from either cell lysate or medium were separated with 4 to $12 \%$ gradient sodium dodecyl sulfate-polyacrylamide gel electrophoresis (SDS-PAGE) and transferred onto polyvinylidene fluoride (PVDF) membranes (Amersham, Buckinghamshire, UK) by semidry blotting. The membranes were blocked by $4 \%$ milk powder-phosphate-buffered saline (PBS) for $2 \mathrm{~h}$, incubated with the primary antibody at $4{ }^{\circ} \mathrm{C}$ overnight, washed, and incubated with the secondary peroxidase-conjugated antibody. Protein bands were detected by film exposure (Bio-Rad, Hercules, CA, USA) to the chemiluminescent product of the enhanced chemiluminescence (ECL) substrate (Pierce, Rockford, IL, USA). Cell lysate was prepared by collecting cells in harvest buffer $\left(130 \mathrm{mM} \mathrm{NaCl}, 3 \mathrm{mM} \mathrm{KCl}, 10 \mathrm{mM} \mathrm{Na}_{2} \mathrm{HPO}_{4}\right.$, $2 \mathrm{mM} \quad \mathrm{KH}_{2} \mathrm{PO}_{4}$, and $10 \mathrm{mM}$ ethylenediaminetetraacetic acid [EDTA]) and centrifugation at $2000 \mathrm{~g}$ for $10 \mathrm{~min}$ at $4{ }^{\circ} \mathrm{C}$. The cell pellet was lysed with RIPA buffer (50 mM Tris [pH 7.4], 1\% NP-40 [Igepal], $0.25 \% \mathrm{Na}$-deoxycholate, $150 \mathrm{mM} \mathrm{NaCl}, 1 \mathrm{mM}$ ethyleneglycoltetraacetic acid [EGTA], $1 \%$ phenylmethylsulfonylfluoride [PMSF], and $1 \%$ protease inhibitor mix) and underwent three freeze-thaw cycles. Debris was separated by $15,000 \mathrm{~g}$ for $15 \mathrm{~min}$ at $4{ }^{\circ} \mathrm{C}$, and the protein concentration of the resulting supernatant was measured. Then $20 \mu \mathrm{g}$ of total protein was loaded onto the gel. Medium was mixed with sample buffer $(5: 1)$ and heated at $95{ }^{\circ} \mathrm{C}$ for $10 \mathrm{~min}$, and the proteins were separated and detected as above. Membranes probed with more than one antibody were stripped prior to reprobing. Antibodies: for human APP (cell lysates), clone $6 E 10$, recognizes human $A \beta_{5-9}$, mouse immunoglobulin $G 1\left(\operatorname{IgG}_{1}\right)$ (Calbiochem, San Diego, CA, USA), dil. 1:500; for A $\beta$, clone 6E10, recognizes $A \beta_{5-9}$, mouse $\operatorname{IgG}_{1}$ (Calbiochem), dil. 1:500; for sAPP (medium samples), clone $22 \mathrm{C} 11, \mathrm{APP}_{66-81}$, mouse $\operatorname{IgG}_{1}$ (Millipore, Billerica, MA, USA), dil. 1:500; for sAPP $\beta$ swe and sAPP $\beta w t$ (medium samples), Ab generated at $\mathrm{H}$. Lundbeck A/S (Valby, Denmark) by immunization of rabbits with conjugates of KLH and 6 C-terminal amino acids of sAPP $\beta$ swe and sAPP $\beta w t$, respectively, dil. 1:50; for sAPP $\alpha$ (medium samples), 6E10 dil. 1:500; secondary Abs, antimouse or anti-rabbit horseradish peroxidase (HRP) conjugate, dil. $1: 5000$.

\section{Immunocytochemistry}

CGCs transfected with APP constructs were subjected to immunofluorescence microscopy for estimation of the transfection efficiency. Cells were washed once in PBS and fixed in $4 \%$ paraformaldehyde, followed by permeabilizing in $0.1 \%$ Triton X-100. Immunostaining was performed using the following antibodies: for huAPPswe, clone 6E10, dil. 1:500; for SEAP-APPswe-EpoR, clone 8B6, recognizes SEAP, mouse $\operatorname{IgG}_{1}$ (GeneTex, San Antonio, TX, USA), dil. 1:100, followed by appropriate secondary antibodies conjugated with either Alexa Fluor 488 or Alexa Fluor 568 (Invitrogen). Nuclei were counterstained with $250 \mathrm{ng} / \mathrm{ml} \mathrm{H}-33342$ (Sigma). Fluorescent images were collected and analyzed using either an MRC-1024 MP laser-scanning confocal microscope (BioRad) or a microscope equipped with an AxioCam charge-coupled device (CCD) camera (Carl Zeiss, Oberkochen, Germany). Antibodies: secondary, anti-mouse HRP conjugate, dil. 1:500.

\section{Statistics}

All experiments are displayed as means of triplicates \pm standard deviations.

One-way analysis of variance and post hoc Student's $t$ tests were employed for statistical evaluation using the statistical software GraphPad Prism (version 4.00 for Windows, GraphPad Software, San Diego, CA, USA).
$\mathrm{IC}_{50}$ values were calculated by performing sigmoidal dose-response curve fitting (GraphPad Prism).

\section{Results}

\section{Neurons from transgenic mice as model for $A \beta$ secretion}

The aim of the current study was to develop cellular model systems for the discovery and pharmacological evaluation of BACE1 modulators or inhibitors. A model for disbalanced $A \beta$ generation that is frequently used in pharmacological research is transgenic mice overexpressing human APP variants. To closely simulate the pharmacological properties of this in vivo test system, CTX neurons were prepared from transgenic mice carrying the Swedish mutation of the 695-amino-acid isoform of APP (APPswe $=\mathrm{KM} \rightarrow \mathrm{NL}$ exchange at the amino acid position 595/596). The variant leads to a significantly higher BACE1-mediated cleavage of APP and was chosen here because of its advantages for a sensitive cellular BACE1 assay and because of its extensive description in the literature. Initially, CTX neurons prepared from APPswe transgenic mice were examined as a quasiphysiological reference system. To measure APP processing under kinetically defined conditions, the cell culture medium was changed at day $3,4,5$, or 6 to measure the amount of peptide secreted into the fresh medium during the following $24 \mathrm{~h}$. We observed increasing generation of $A \beta_{1-40}$ during maturation of the neuronal cultures, with 24 -h period production values ranging from $100 \mathrm{pg} / \mathrm{ml}$ at $3 \mathrm{DIV}$, to more than $200 \mathrm{pg} / \mathrm{ml}$ at $4 \mathrm{DIV}$, to $400 \mathrm{pg} / \mathrm{ml}$ at $5 \mathrm{DIV}$, to a stable $A \beta$ generation in cultures older than 6 DIV (600 pg/ml within $24 \mathrm{~h}$ ). For further experiments, we chose to measure peptide secretion within the 24 -h period between days 6 and 7 after plating of the neurons. Under these conditions, approximately $60 \mathrm{pg}$ of $A \beta_{1-40}$ and $8 \mathrm{pg}$ of $A \beta_{1-42}$ were produced by approximately 100,000 neurons (Fig. $1 \mathrm{~A}$ and $\mathrm{B}$ ). Thus, the ratio of $A \beta_{1-40} / A \beta_{1-42}$ was roughly $7: 1$, which is in accordance with data from the literature. For the pharmacological characterization of the role of $\beta$-secretase and $\gamma$-secretase in $A \beta$ generation in this system, we used two potent and selective BACE1 inhibitors, designated here as IPAD and AQD (Fig. 1C), and the potent $\gamma$-secretase inhibitor DAPT [33] (not shown). All compounds led to a concentration-dependent and nearly complete inhibition of $A \beta_{1-40}$ and $A \beta_{1-42}$ generation. Most important, the $\mathrm{IC}_{50}$ values for the BACE1 inhibitors (Fig. 1A and B) and for DAPT (90 nM) were in the range expected for these compounds in a cellular test system.

Although CTX neurons correspond most closely to the brain region affected in $\mathrm{AD}$, we also evaluated CGCs as an alternative culture system with related pharmacological properties but large technical advantages (e.g., homogeneity, yield, postnatal preparation, genetic manipulation). CGCs from APPswe transgenic mice produced $A \beta_{1-40}$ already during the initial $24 \mathrm{~h}$ after plating. During the following 6 days, the production per day increased from $100 \mathrm{pg} / \mathrm{ml}$ after $24 \mathrm{~h}$ to approximately $500 \mathrm{pg} / \mathrm{ml}$ for 200,000 cells at 3 DIV, where it stayed relatively constant for the following culture days. For further measurements, we chose the period between days 3 and 4 past plating to evaluate BACE1-dependent APP processing. Under these conditions, approximately $50 \mathrm{pg}$ of $A \beta_{1-40}$ and $10 \mathrm{pg}$ of $A \beta_{1-42}$ were produced by approximately 200,000 neurons (Fig. 1D and E). For the pharmacological characterization of the role of secretases in this system, we used IPAD, AQD, and DAPT. All compounds behaved pharmacologically as would be expected from a suitable test system (Fig. $1 \mathrm{D}$ and $\mathrm{E}$; $\mathrm{IC}_{50} \mathrm{DAPT}=120 \mathrm{nM}$ ). The production capacity for $A \beta$ peptides, as well as the pharmacological properties of the system, suggests that CGCs can form a robust basis for a cellular BACE1 assay. However, the transgenic CGCs have some technical disadvantages such as their fixed background and the requirement for large transgenic breeding stocks. Also, 


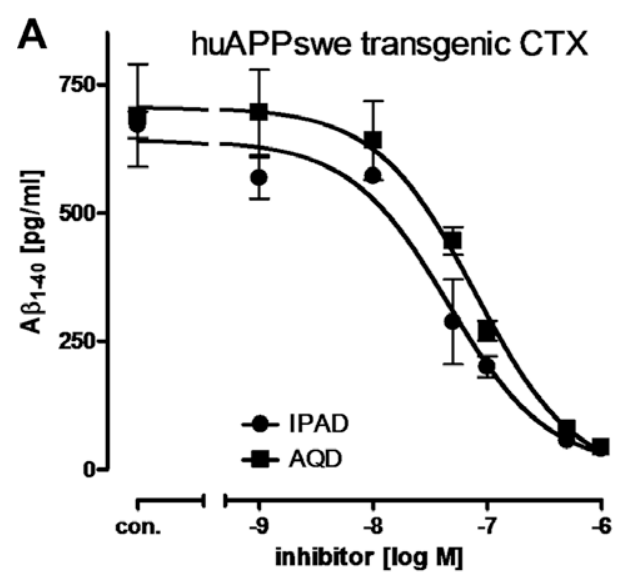

C BACE1 inhibitors<smiles>CC(C)[C@H](C)OC(=O)c1cc(C(=O)N[C@H](c2ccccc2)[C@@H](O)CNC2CC2)cc(N(C)S(C)(=O)=O)c1</smiles>

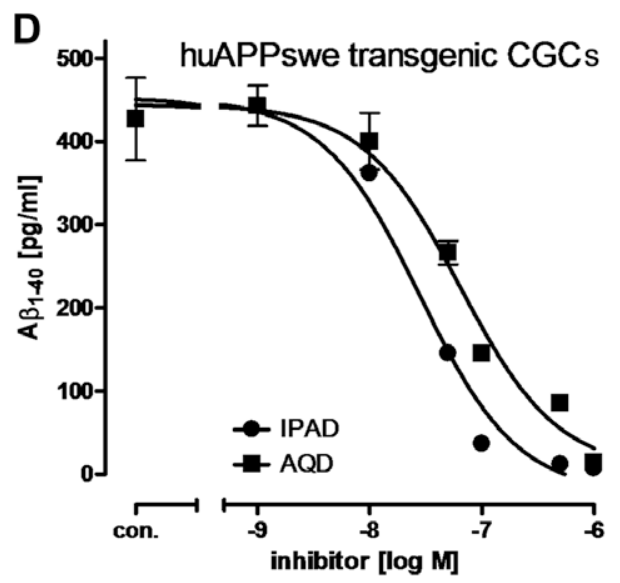

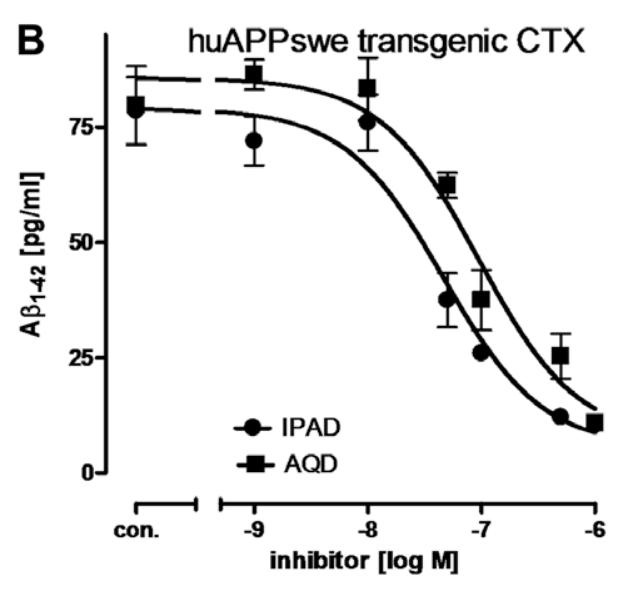

AQD:

Aminoquinazoline-Derivative<smiles>CN(C(=O)CCC(C1CCCCC1)N1Cc2cc(Oc3ccccc3)ccc2N=C1N)C1CCCCC1</smiles>

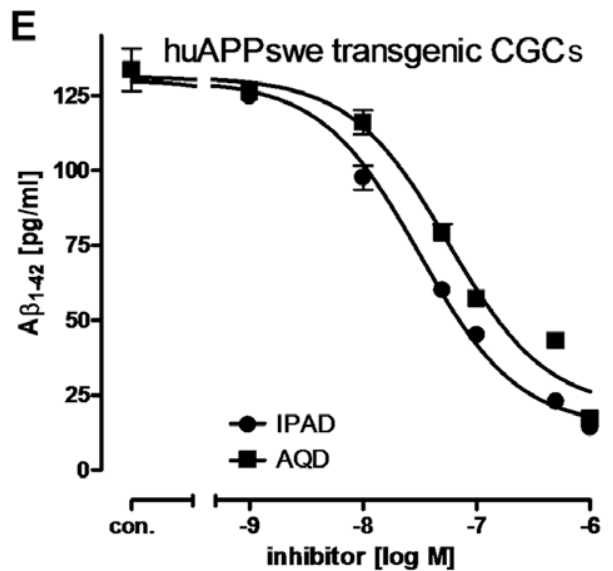

Fig. 1. Inhibition of $A \beta_{1-40}$ and $A \beta_{1-42}$ generation in neurons by BACE1 inhibitors IPAD and $A Q D$. CTX neurons (A,B) and CGCs (D,E) isolated from transgenic mice overexpressing human APP with Swedish mutation were incubated with BACE1 inhibitors at concentrations as indicated. After $24 \mathrm{~h}$, secreted A $\beta$ was measured from the supernatant medium by ELISA specific for $A \beta_{1-40}(A, D)$ or $A \beta_{1-42}(B, E)$. (C) Chemical structures of IPAD and $A Q D$. The following IC $C_{50}$ values were calculated for IPAD and $A Q D$, respectively: (A) 40 and $70 \mathrm{nM}$; (B) 45 and $75 \mathrm{nM}$; (D) 30 and $60 \mathrm{nM}$; (E) 35 and $65 \mathrm{nM}$.

many transgenic APP mice used as AD models, including the ones used here, harbor additional modified genes such as mutated $\gamma$-secretase.

Transient transfection of CGCs with APP constructs as a model for APP processing

We tested an alternative approach by using wild-type CGCs transfected with the human APP gene of interest. In a first step, the efficiency of different transfection methods was optimized using GFP as a target construct. Different liposome transfection approaches never yielded more than $5 \%$ transfected neurons. Therefore, we optimized the gene transfer by electroporation and finally achieved transfection efficiencies of 40 to 60\% using Amaxa nucleofection. This method was also suitable for overexpression of APPswe, which was expressed in more than $40 \%$ of nucleoporated CGCs as assessed by immunostaining and GFP cotransfection (Fig. 2A). This new model of CGCs expressing APPswe was characterized biochemically; human APP was processed correctly along the relevant pathways in CGCs to yield $\operatorname{sAPP} \alpha, s A P P \beta$ (Fig. 2B), and $A \beta$ (Figs. $2 C$ and $3 A$ ) in the supernatant. As expected, an increasing extent of inhibition of BACE1 (by IPAD) resulted in decreasing levels of SAPP $\beta$ secretion. Interestingly, the total amount of SAPP remained relatively constant, and we found that this is due to a relative increase of SAPP $\alpha$ under conditions of BACE1 inhibition (Fig. 2B). Notably, the total sAPP in our experiments contains ectopic human and endogenous murine protein due to cross-reactivity of the antibody used, whereas the detection 
A

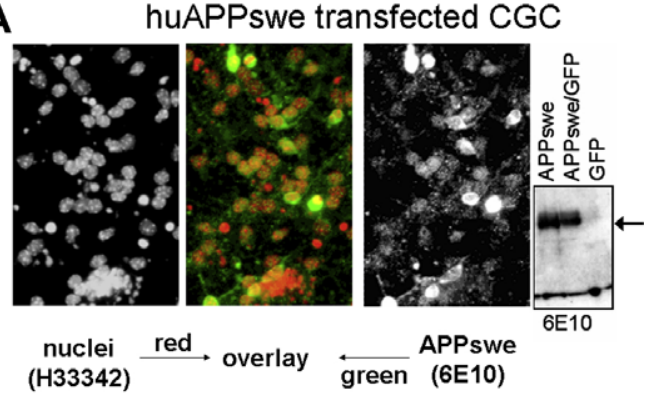

B

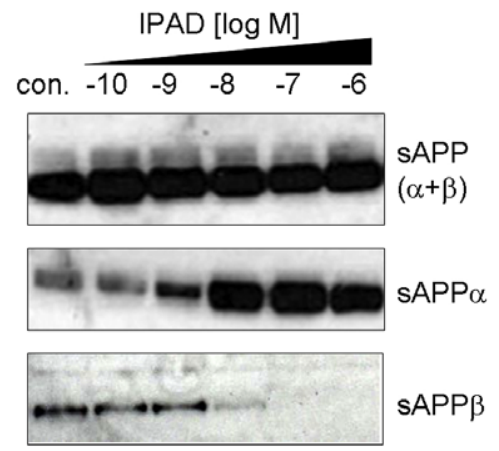

C

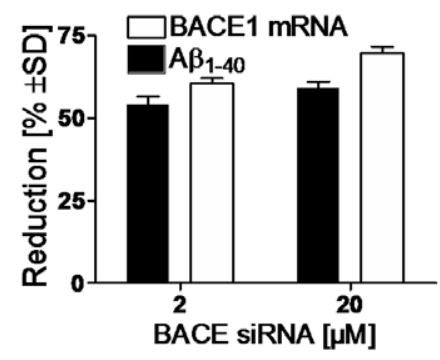

D

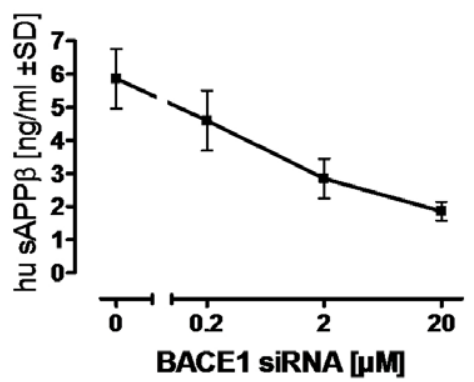

Fig. 2. BACE1-dependent cleavage of huAPPswe in CGCs after gene expression following electroporation. (A) CGCs transfected with huAPPswe were fixed after $48 \mathrm{~h}$ and stained. Nuclei are visualized with H33342 (red in the fusion image) and APP with the human APP-specific antibody $6 \mathrm{E} 10$ (green in the fusion image). The image width corresponds to $70 \mu \mathrm{m}$. Western blot (right) shows expression of huAPPswe protein in neurons transfected with APP or cotransfected with APP plus GFP (indicated by arrow) but not in control cells transfected with GFP only. (B) CGCs were transfected with huAPPswe and cultured for 3 days. Then the medium was changed to administer IPAD at the concentrations indicated, predissolved or not (con.) in the same volumes of dimethyl sulfoxide (DMSO). After $24 \mathrm{~h}$, the medium was collected to measure secreted sAPP species by immunoblot. Total sAPP ( $\mathrm{SAPP} \alpha$ and SAPP $\beta$ ) was detected using antibody 22C11, sAPP $\alpha$ was detected using antibody $6 \mathrm{E} 10$, and SAPP $\beta$ was detected using a cleavage site-specific APPswe antibody. (C) CGCs were cotransfected with huAPPswe and siRNA for BACE1 or scrambled control (con.) at the concentrations indicated. After $48 \mathrm{~h}$, the medium was collected to measure secreted human $A \beta_{1-40}$ by ELISA (diagram). BACE1 mRNA levels were measured by real-time PCR. (D) The medium from the same experimental setup as in panel $C$ was used in an ELISA specific for human SAPP $\beta$. (C,D) Data are means \pm standard deviations of three different experiments and are presented in relation to scrambled control siRNA.

for SAPP $\alpha$ and SAPP $\beta$ was specific for human protein. For further validation, we exploited the fact that additional nucleic acid frag-
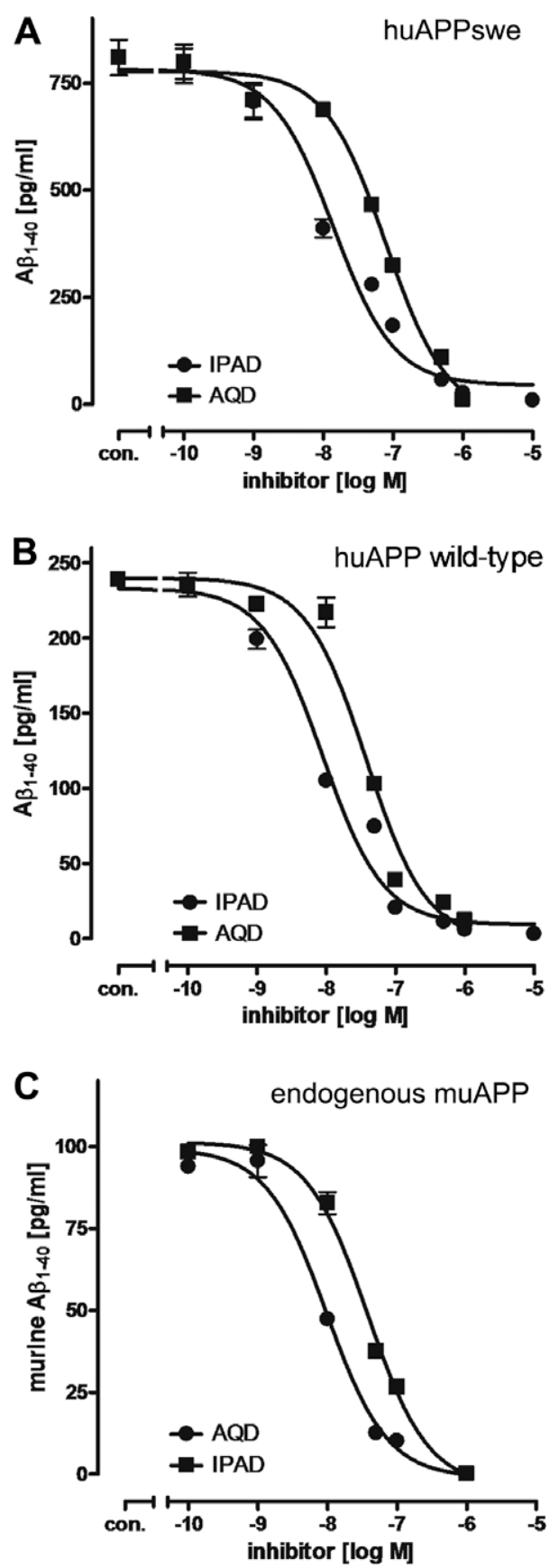

Fig. 3. Inhibition of $A \beta$ generation in wild-type CGCs by BACE1 inhibitors. CGCS transfected with human APPswe (A), CGCs transfected with human APP (B), and nontransfected CGCs (C) were cultured for 3 days and then incubated in fresh medium with BACE1 inhibitors at the concentrations indicated for $24 \mathrm{~h}$. Secreted $A \beta_{1-40}$ was measured from the supernatant medium by ELISA for human $A \beta_{1-40}$ $(A, B)$ or rodent $A \beta_{1-40}(C)$. The following IC $C_{50}$ values were calculated for IPAD and AQD, respectively: (A) 15 and $80 \mathrm{nM}$; (B) 10 and $40 \mathrm{nM}$; (C) 10 and $40 \mathrm{nM}$.

ments can be introduced into the cells together with APP expression plasmid during electroporation. To demonstrate the essential role of BACE1 in the model system we cotransfected cells with siRNA for BACE1 (or control siRNA) and APPswe. After $48 \mathrm{~h}$, we observed a specific down-regulation of BACE1 mRNA by 60 to $70 \%$, which was paralleled by a reduction of $A \beta$ secretion of approximately 50 to $60 \%$ (Fig. 2C) and of SAPP $\beta$ by up to $80 \%$ (Fig. 2D). BACE1 activity could not be down-regulated further by this approach, most likely due to the known long half-life $(8 \mathrm{~h})$ of the enzyme and the maximal transfection efficiency of 60 to $70 \%$ for siRNA in CGCs. 
Pharmacological validation of BACE1-dependent processing of human $A P P$ in murine CGCS

After the basic biochemical examination, $A \beta$ generation was characterized meticulously. We detected significant amounts of human $A \beta(100 \mathrm{pg} / \mathrm{ml}$ produced by 1 million cells $)$ in medium samples already after $24 \mathrm{~h}$. During the following 3 days, the production per day stayed relatively constant in the $350 \mathrm{pg} / \mathrm{ml} / 24 \mathrm{~h}$ range and then started decreasing. For all further experiments, we measured $A \beta$ generation in the $24-$ to 72 -h period after transfection. Under these conditions, approximately $80 \mathrm{pg}$ of $A \beta_{1-40}$ (Fig. $3 \mathrm{~A}$ ) and $6 \mathrm{pg}$ of $A \beta_{1-42}$ (data not shown) were produced within $48 \mathrm{~h}$. Thus, the ratio of $A \beta_{1-40} / A \beta_{1-42}$ was roughly $12: 1$, which is in accordance with data for neurons with normal $\gamma$-secretase.

For the pharmacological characterization of the role of $\gamma$-secretase in $A \beta$ generation in this system, we used four potent and selective $\gamma$-secretase inhibitors: DAPT [33], GSI-18 [34], GSI-19 [35], and LY450139 [36]. All compounds led to a concentration-dependent and nearly complete inhibition of $A \beta_{1-40}$ and $A \beta_{1-42}$ generation with $\mathrm{IC}_{50}$ values of $60,0.5,0.2,125 \mathrm{nM}$, respectively.

$\mathrm{A} \beta$ secretion was also inhibited in a concentration-dependent manner by both IPAD and AQD (Fig. 3A). To investigate whether the Swedish mutation in APP affected the pharmacological activity of BACE1 inhibitors in that model system, the same experiment was repeated with APPwt-overexpressing CGCs and revealed similar $\mathrm{IC}_{50}$ values (Fig. 3B). Compared with APPswe, APPwt expression resulted in a threefold lower $A \beta$ peptide production. As a final validation, we examined whether the transfection stress itself or the use of human APP in murine cells may affect data obtained with BACE1 inhibitors. For this purpose, nontransfected CGCs were treated with the two BACE1 inhibitors, and production of endogenous murine $A \beta$ was measured. The similarity of the inhibition curves and $\mathrm{IC}_{50}$ values compared with human APPswe transfected cells clearly indicates that overexpression of APPswe is a representative model for endogenous APP processing (Fig. 3C). Notably, the antibodies used in the ELISA for human $A \beta$ do not cross-react with murine $A \beta$. Thus, endogenous $A \beta$ is usually not detected in transfected neurons. In conclusion, endogenous production of murine $A \beta$ alone may be an important and useful model system for certain questions provided that a method for detection of murine $A \beta$ is available. However, for many laboratories, the high costs of such ELISA kits for $A \beta$ detection preclude their use. The results obtained with nucleofected cells clearly indicate that primary CGCs serve as a suitable system to study mechanistic aspects of APP processing by genetic overexpression or knockdown of targets of interest.

\section{Use of SEAP for enzymatic detection of cellular BACE1 activity}

For pharmacological purposes, it is highly desirable to render a cellular BACE1 assay as specific as possible. In the assay variants presented above, $\gamma$-secretase inhibitors also interfered with the assays, with the only exception being the measurement of SAPP $\beta$ (Fig. 2B and D). However, the Western-blot-based detection method allows only limited quantitative information and puts a high strain on resources, as does the SAPP $\beta$ ELISA. Therefore, we designed an assay system based on the enzymatic measurement of SEAP activity as a surrogate for secreted APP. For this purpose, the N-terminal part of APP in our expression constructs was substituted for SEAP. The new plasmid was initially tested in HEK293 cells. These allowed rapid biochemical and pharmacological validation because they express human BACE1 and $\gamma$-secretase but only very limited amounts of endogenous APP. On transfection of an SEAP-APPswe fusion construct, we found high SEAP activities and $A \beta$ amounts to be secreted into the cell culture medium in a strictly time- and cell-number-dependent way. A $\beta$ and SEAP secretion correlated well with one another (Fig. 4A). For a basic charac- terization, the SEAP-APPswe construct was cotransfected together with siRNA for SEAP, APPswe (not shown), or BACE1 (Fig. 4B). The former two siRNAs served as internal positive controls. They showed the expected effect of a strong reduction of SEAP secretion and inhibition of $A \beta$ production (APPswe siRNA by $80 \%$ ). In view of these well-working controls, it was surprising that BACE1 knockdown had no significant effect on SEAP secretion, although $A \beta_{1-40}$ secretion was reduced by more than $50 \%$ (Fig. 4A) and also BACE1
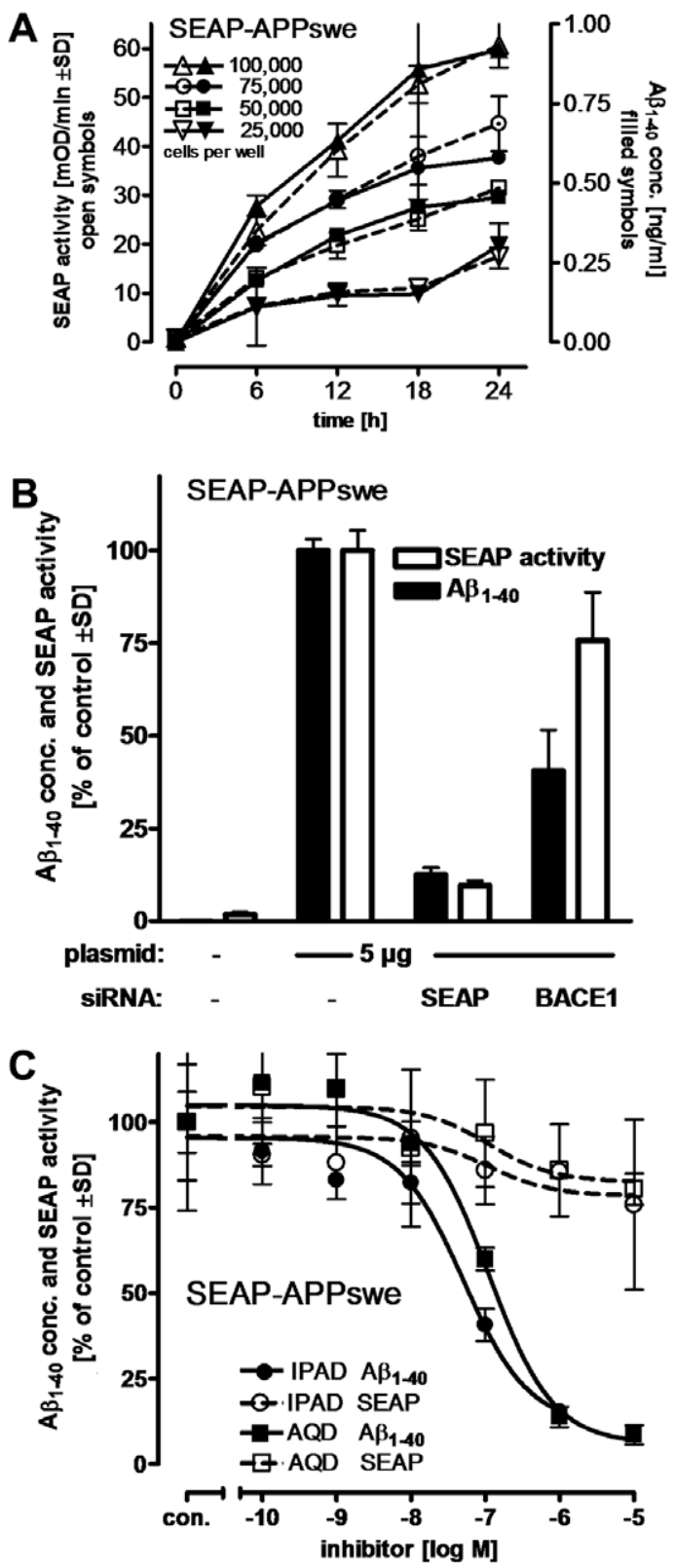

Fig. 4. Characterization of the fusion protein construct SEAP-APPswe with siRNA and BACE1 inhibitors. (A) HEK293 cells were transfected with SEAP-APPswe and seeded at different cell numbers per well. Samples were taken from the supernatant at the time points indicated, and SEAP activity was determined. (B) HEK293 cells were transfected with SEAP-APPswe only or were cotransfected with siRNA for SEAP, APPswe, or BACE1, the medium was changed after $24 \mathrm{~h}$, and it was sampled after an additional $24 \mathrm{~h}$. At $24 \mathrm{~h}$ after the medium change, secreted $A \beta_{1-40}$ concentrations and SEAP activity were measured in the medium and normalized to controls. (C) HEK293 cells were transfected with SEAP-APPswe, and after $24 \mathrm{~h}$ the medium was changed and BACE1 inhibitors IPAD and AQD were added at the concentrations indicated before medium SEAP activity was determined $24 \mathrm{~h}$ later. The calculated $\mathrm{IC}_{50}$ value for IPAD was $50 \mathrm{nM}\left(\mathrm{A} \beta_{1-40}\right)$, and that for AQD was $110 \mathrm{nM}$ $\left(\mathrm{A} \beta_{1-40}\right.$ and SEAP). 
mRNA was reduced by $50 \%$ (not shown). When the BACE1 inhibitors IPAD and AQD were used as established and potent pharmacological tools, again SEAP release was hardly inhibited even at the highest inhibitor concentration, whereas $A \beta_{1-40}$ secretion was strongly blocked (Fig. 4C). Taken together, these findings indicate that SEAP secretion under these conditions was less strictly BACE1 dependent than $A \beta$ formation. A likely explanation is that SEAP, like sAPP, is secreted not only due to BACE1 activity but also due to $\alpha$-secretase activity (Fig. $5 \mathrm{~A}$ and $\mathrm{B}$ ). To circumvent this problem, the SEAP-APP constructs were optimized accordingly (Fig. 5C and D).

Validation of APP constructs with $\alpha$-cleavage site mutation in HEK293 cells

Because $\alpha$-secretase activity is constituted of various enzymes with distinct enzymatic properties, the $\alpha$-cleavage consensus sequence is not sharply defined [45,46]. Nevertheless, several APP mutations that render APP a less good substrate of $\alpha$-secretase have been described [46-48]. However, cleavage is only partially reduced, and some of the mutations strongly affect the structure of APP or A $\beta$. To improve on this situation, here we tried various mutations within the $\alpha$-secretase recognition sequence (A $\beta$ amino acids 14-21) that may be useful for a selective BACE1 assay. Mu-

\section{A APPswe}

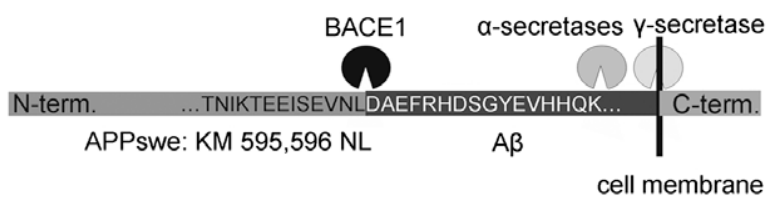

B SEAP-APPswe

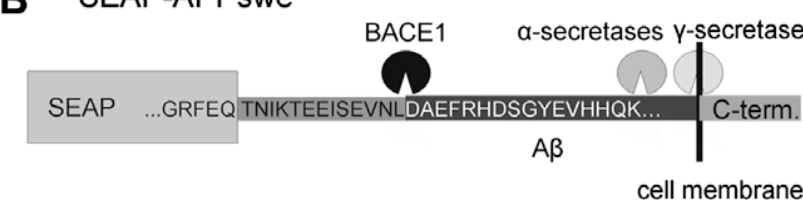

\section{SEAP-APPWt-AßK16V}

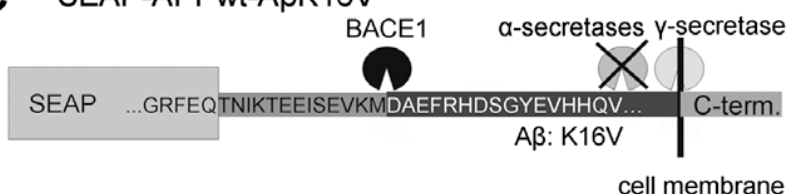

\section{SEAP-APPswe-EpoR}

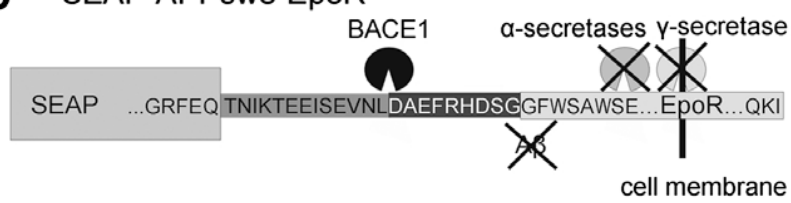

Fig. 5. Description of APP constructs introduced in this study. (A) APPswe encodes here for the APP isoform with 695 amino acids and the double mutation K595N/ M596L under the control of a CMV promoter. It is processed canonically by $\beta$ - and $\alpha$-secretases, generating an $\mathrm{N}$-terminal sAPP $\alpha$ or sAPP $\beta$ fragment $(\mathrm{N}$-term) and a C-terminal C99 or C83 fragment (C-term), respectively. The C-terminal fragment generated by BACE1 is further cleaved by $\gamma$-secretase to generate A $\beta$. (B-D) Here part of $\mathrm{N}$-term was substituted by SEAP to generate SEAP-APP fusion proteins. Both SEAP-APPswe and SEAP-APPwt contain all three cleavage sites for $\alpha-, \beta$ - and $\gamma$-secretases. (C) SEAP-APPwt-A $\beta$ K16V (K612 V) has a mutated $\alpha$-cleavage site and wild-type cleavage sites for $\beta$ - and $\gamma$-secretases. (D) SEAP-APPswe-EpoR has the $\alpha$ - and $\gamma$-cleavage sites deleted by substitution of the $C$ terminus of APP for the EpoR transmembrane domain and, therefore, contains only the $\beta$-cleavage site. tants of SEAP-APP were tested in an initial prescreen on transfected HEK293 cells based on their property to facilitate inhibition of SEAP secretion by IPAD. For instance, lysine (K) at position 16 of $A \beta$ (position 612 in APP 695) was substituted by a charged glutamate (E) or hydrophobic valine (V). Finally, we focused on the ABK16V mutation (Fig. 5C), which was most promising (not shown). In cells expressing the SEAP-APPwt-ABK16V construct, inhibition of SEAP secretion by BACE inhibitors was nearly complete (Fig. 6). Most important, inhibition of SEAP by IPAD and AQD correlated to a high degree with inhibition of $A \beta$ formation. This single amino acid mutation construct, therefore, provided proof of principle that a cellular assay that selectively detects inhibitors and modulators of BACE1 can be constructed. The disadvantage of this approach was that the measurable SEAP activity and $A \beta$ release were low (1-5\% compared with wild type) and assay variation was accordingly high when using the construct without BACE1 cotransfection.

Substitution of $\alpha$ - and $\gamma$-cleavage sites of APP for generation of BACE1dependent assay system in HEK293 cells

The entire $\alpha$-site, transmembrane domain, and C-terminal AICD were replaced by the membrane spanning domain of the EpoR to generate a membrane protein construct containing only a BACE1 cleavage site (Fig. 5D). This construct underwent a basic characterization in HEK293 cells. Following transfection, SEAP was secreted into the medium also in a strictly time- and cell-number-dependent way (Fig. 7A). Secreted SEAP activity was again strongly reduced on cotransfection with SEAP siRNA or APPswe siRNA (not shown). The reduction in SEAP secretion correlated with the strong knockdown effect on mRNA levels in comparison with cells cotransfected with siRNA against GFP only (Fig. 7B). In contrast to constructs with intact $\alpha$-site, BACE1 siRNA treatment resulted in a clear-cut reduction in SEAP secretion of SEAP-APPswe-EpoR cells. These observations demonstrate that BACE1 is decisively involved in SEAP-APPswe processing in this new type of assay system (Fig. 7B). This was further tested by a pharmacological approach; IPAD and AQD inhibited SEAP secretion in SEAP-APPswe-EpoR cells, with similar $\mathrm{IC}_{50}$ values as in the systems described earlier (Fig. 7C), whereas the $\gamma$-secretase inhibitor LY450139 (up to $10 \mu \mathrm{M}$ ) had no effect (not shown). The system showed some residual SEAP secretion that could not be blocked

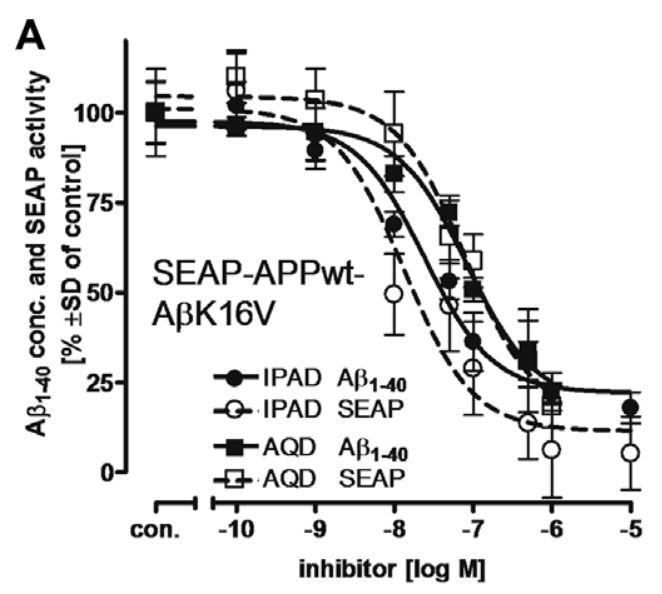

Fig. 6. Characterization of SEAP-APPwt-ABK16V. HEK293 cells were cotransfected with SEAP-APPwt-ABK16V and BACE1, and after $24 \mathrm{~h}$ BACE1 inhibitors IPAD and $A Q D$ were added by a medium change at the concentrations indicated. Then, $24 \mathrm{~h}$ after the medium change, secreted $A \beta_{1-40}$ concentrations and SEAP activity were measured in the medium and normalized to controls. The calculated $\mathrm{IC}_{50}$ values for IPAD were $25 \mathrm{nM}\left(\mathrm{A} \beta_{1-40}\right)$ and $15 \mathrm{nM}$ (SEAP), and those for AQD were $85 \mathrm{nM}$ $\left(\mathrm{A} \beta_{1-40}\right)$ and $80 \mathrm{nM}(\mathrm{SEAP})$. 

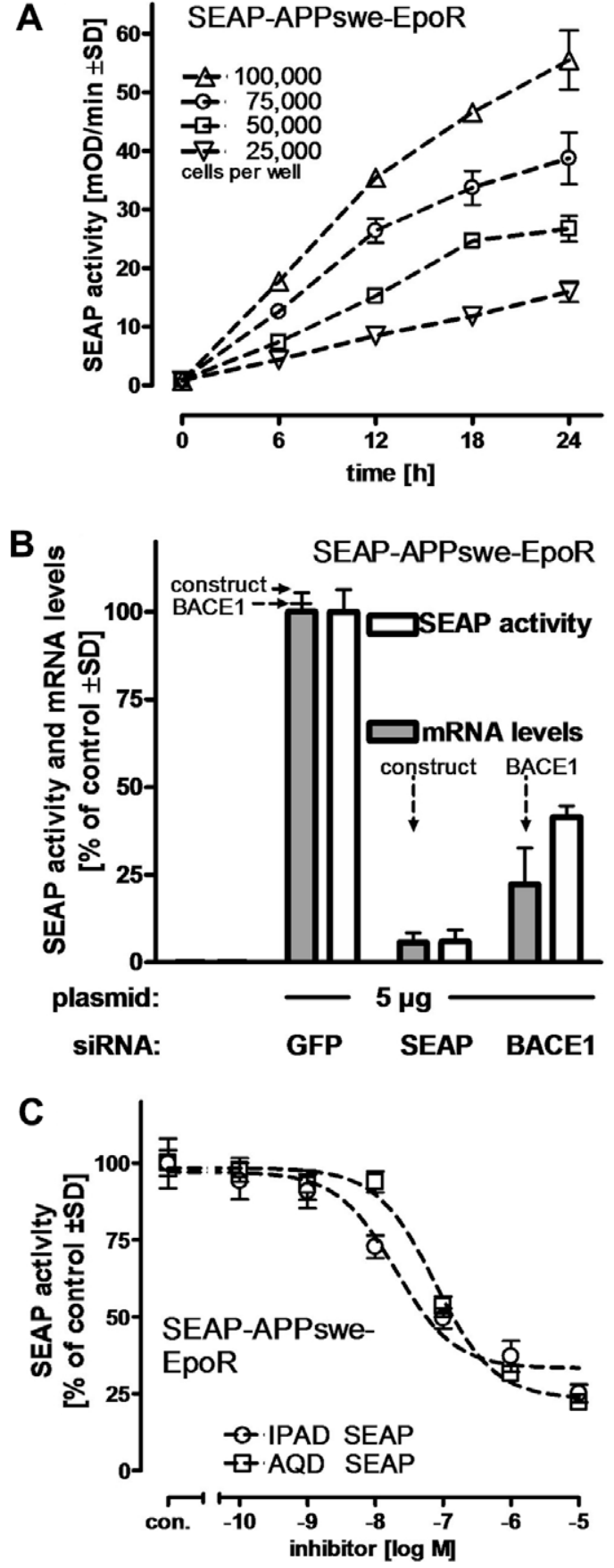

Fig. 7. Characterization of SEAP-APPswe-EpoR. (A) HEK293 cells were transfected with SEAP-APPswe-EpoR and seeded at different cell numbers per well. Samples were taken at the time points indicated, and SEAP activity was determined. (B,C) HEK293 cells were cotransfected (B) with SEAP-APPswe and siRNA for GFP, SEAP, APPswe, or BACE1, followed by a medium change after $24 \mathrm{~h}$, or were transfected with SEAP-APPswe only (C), followed after $24 \mathrm{~h}$ by a medium change with the addition of BACE1 inhibitors IPAD and AQD at the concentrations indicated. Then, $24 \mathrm{~h}$ after the medium change, secreted $A \beta_{1-40}$ concentrations and SEAP activity were measured in the medium and normalized to controls (siRNA for GFP in panel $\mathrm{B}$; no inhibitor in panel C). The calculated $\mathrm{IC}_{50}$ values for IPAD and AQD were 20 and $75 \mathrm{nM}$, respectively.

either by BACE1 inhibitors or by the unspecific $\alpha$-secretase inhibitor GM6001 (at $10 \mu \mathrm{M}$ ). A large technical advantage of the system (e.g., for larger screens) was the high secreted SEAP activity and high robustness, which resulted in small experimental errors (Fig. 7C).
A neuronal model to selectively study BACE1 activity and its pharmacological modulation

We transferred the SEAP constructs validated in HEK293 cells to primary CGCs. First, SEAP-APPswe was characterized after transfection into neurons. IPAD and AQD inhibited $A \beta$ secretion to a large extent (by $\sim 80 \%$ ), whereas SEAP release was only partially inhibited (40-60\%) (Fig. 8A). Thus, also here $\alpha$-secretase appears to interfere with the assay, but less strongly than in HEK293 cells. Therefore, SEAP-APPswe-EpoR was tested as an alternative. The transfection efficiency was approximately 40\% (Fig. 8B), that is, similar to nonmodified APP constructs. The two BACE1 inhibitors now resulted in a reduction of SEAP release by $80 \%$ (Fig. $8 \mathrm{C}$ ), the system showed little variation, and the pharmacological character-

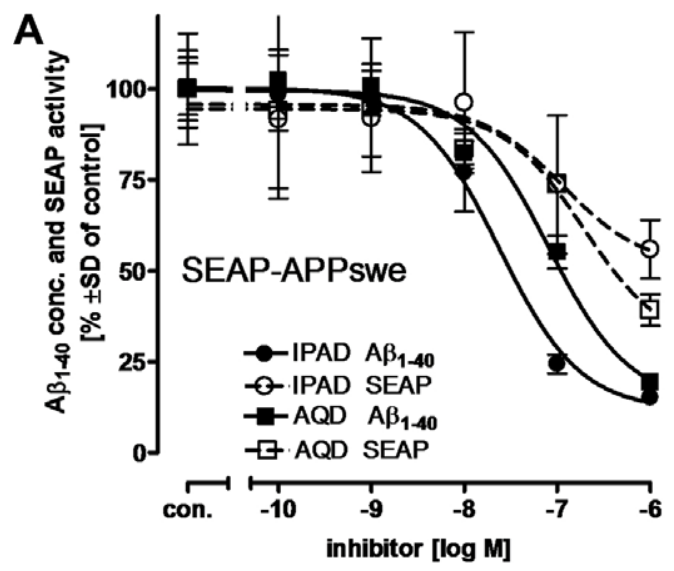

B SEAP-APPswe-EpoR transfected CGCs
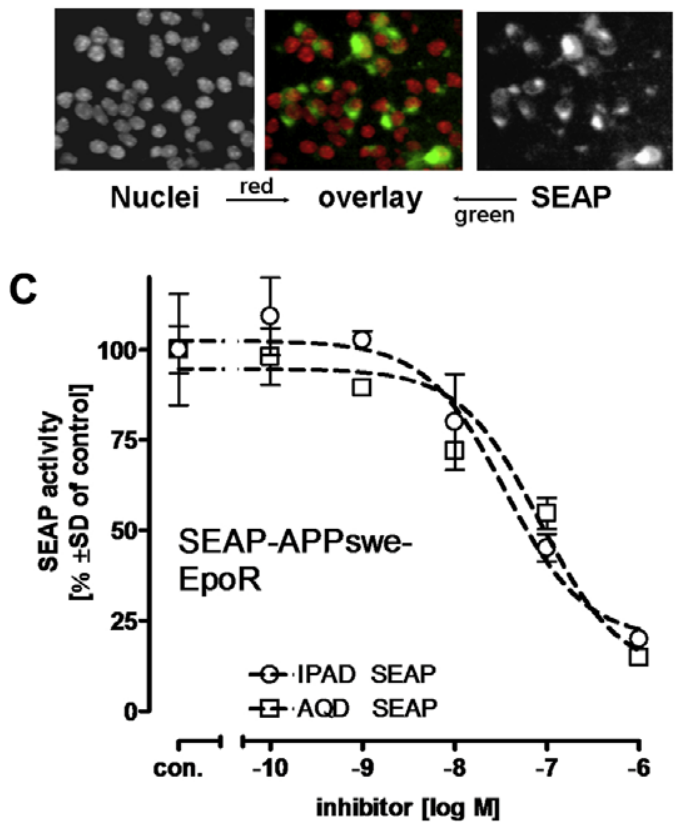

Fig. 8. Inhibition of cleavage of SEAP-APP fusion proteins in CGCs. CGCs were transfected with SEAP-APPswe (A) or SEAP-APPswe-EpoR (C). After $48 \mathrm{~h}$, the medium was changed and BACE1 inhibitors were added at the concentrations indicated. Secreted $A \beta_{1-40}(A)$ and SEAP activity $(A, C)$ were measured in the medium. The calculated $I C_{50}$ values for IPAD were $15 \mathrm{nM}\left(\mathrm{A} \beta_{1-40}\right)$ and $115 \mathrm{nM}$ (SEAP) $(A)$ and $35 \mathrm{nM}\left(\mathrm{A} \beta_{1-40}\right)(C)$, and those for AQD were $80 \mathrm{nM}\left(\mathrm{A} \beta_{1-40}\right)$ and 190 $\mathrm{nM}$ (SEAP) (A) and $85 \mathrm{nM}$ (SEAP) (C). (B) CGCs transfected with SEAP-APPswe-EpoR for $48 \mathrm{~h}$ were fixed and stained for SEAP and DNA. Nuclei were visualized with $\mathrm{H} 33342$ (red in the fusion image). SEAP staining is shown in the green channel in the merged image. The transfection efficiency (i.e., percentage of neurons expressing SEAP) was approximately $40 \%$. The image width corresponds to $70 \mu \mathrm{m}$. 
istics of the compounds were similar to those found in the assay systems described above. These results indicate that the system composed of primary CGCs transfected with the SEAP-APPsweEpoR construct allows the study of BACE1 activity and its direct or indirect pharmacological modulation in the natural environment of a neuronal cell.

\section{Discussion}

$A \beta$ is one of the most prominent biochemical markers of $A D$ pathology, even though a direct causal relationship between the overproduction of $A \beta$ and the etiology of this neurodegenerative disorder still awaits pharmacological validation. Such confirmation could be achieved if BACE1 inhibitors would slow disease progression in humans, and the search for such therapeutically active compounds is a major focus of AD drug discovery. Currently available test systems that measure cellular BACE1 activity, such as nonmammalian cells $[49,50]$, allow only low throughput or are based on labor- and cost-intensive detection methods such as high-performance liquid chromatography (HPLC), ELISA, and Western blot [51,52]. In the current study, we have presented novel approaches to BACE1 activity screening that use the normal neuronal environment of the protease and allow high throughput at low cost. These test systems allow both basic cell biological studies on the upstream regulation of BACE1 activity and specific assessment of pharmacological or genetic interventions. With respect to the substrates presented here, it needs to be noted that many potentially important functional domains of APP are lost. For instance, the EPO-R construct may be artificially tethered to the plasma membrane or may show trafficking behavior different from that of normal APP with its membrane domain and intracellular C-terminal tail of APP.

\section{Validation of a reference model}

Genetically modified mouse strains have allowed elegant studies on overexpression or knockdown of targets of interest in the field of $A D$ research. To boost the generation of detectable $A \beta$ plaques in the brain, APP overexpression was combined in mice with a mutation in the presenilin gene of $\gamma$-secretase. Moreover, to circumvent the problem of low endogenous basal $A \beta$ release, transgenic mice overexpressing the human Swedish form of APP instead of APPwt were generated [37]. The Swedish mutation specifies an amino acid exchange in the $\beta$-secretase cleavage site of APP and results in an elevated cleavage rate, thereby extending the detection range of the assay systems applied [53]. As a general reference system for our studies, primary neurons obtained from the CTX lobes of such mice were isolated. In addition, CGCs were introduced as a model system. The latter cells do not reflect the region of brain pathology in AD such as CTX, but they allow postnatal isolation, higher cell yields, and reproducible postisolation genetic manipulations of a very homogeneous neuronal population. Similar to previous literature data [54], the ratio between $A \beta_{1-40}$ and $A \beta_{1-42}$ was approximately 7:1 in CTX obtained from APPswe transgenic mice. CGCs showed a more pronounced (ratio of $\sim 5: 1$ ) formation of $A \beta_{1-42}$, which is generally considered as the more "toxic" and more aggregation-prone form. An essential observation with regard to the robustness of the model was our finding of similar IC $_{50}$ values for two BACE1 inhibitors in CTX and CGCs from huAPPswe transgenic mice (Fig. 1 ). These cellular $\mathrm{IC}_{50}$ values also resemble the literature data obtained on isolated BACE1 enzyme $[31,32]$. The two inhibitors used in the current study (IPAD and $A Q D)$ are typical peptide-based substrate analogues in which the characteristic amide bond is replaced by a noncleavable transition state isostere. This class of inhibitors revealed high specificities and potencies in our reference models, as predicted by previous studies for IPAD [52]. Until now, AQD had been only little characterized on cellular systems, and our studies on primary neurons extend the pharmacological knowledge on both compounds. Notably, cell viability following treatment with the BACE1 inhibitors was routinely controlled in all of our studies and was not significantly affected. Thus, neuronal cultures from APPswe transgenic mice indeed worked well as a reference model. However, this system is severely limited in its flexibility (e.g., for additional genetic interventions) and requires a very extensive infrastructure for neuronal supply and analysis of $A \beta$.

\section{Primary wild-type CGCs as alternative test system}

For the establishment of a more versatile cellular model, the observations made with huAPPsw transgenic CTX neurons and CGCs served as a general reference standard. As a variable alternative, primary CGCs obtained from wild-type mice were introduced, and these cells were transfected with different APP overexpression constructs or siRNA. With a reproducible transfection efficiency of more than $40 \%$ and an siRNA knockdown efficiency of approximately 60 to $70 \%$, this system represents a highly flexible model to study the impact of the various components and modifications of the APP processing cascade (Fig. 2). Most important, for a potential application of the model in BACE1 inhibitor candidate testing, the observed $\mathrm{IC}_{50}$ values obtained with IPAD or AQD were in accordance with data obtained in our reference model. Direct comparison of $A \beta_{1-40}$ generation in APPwt versus APPswe transfected cells revealed a threefold higher production of $A \beta_{1-40}$ when APPswe was transfected (Fig. 3A and B). Notably, only half the amount of APPswe plasmid compared with huAPPwt was used. Thus, one may assume that the Swedish mutation results in a sixfold higher $A \beta_{1-40}$ release compared with the wild type, which is similar to previous results [55]. Employment of the Swedish mutant, therefore, allows higher assay sensitivity without compromising specificity.

\section{HEK293 cells as platform for assay optimization}

One of the primary intentions of the current study was the substitution of the cost- and labor-intensive detection of $A \beta$, typically performed by ELISA, HPLC, or Western blot analysis, by a simple readout system. In alternative assay systems, optimized BACE1 substrates that become fluorescent on cleavage have been described. However, this kind of approach appears to be suitable only for pure biochemical test systems [56]. Instead, we modified an approach that had already been tested successfully in an $\alpha$-secretase assay [57]. The $\mathrm{N}$ terminus of APP was substituted by alkaline phosphatase, and the enzymatic activity of SEAP released into the cell culture supernatant was used as an alternative readout for the proteolytic action of BACE1. The use of SEAP as a reporter enzyme has the advantage over other alternatives that its activity is detected at $\mathrm{pH} 10.5$. This assay condition almost completely precludes the involvement of other cellular phosphatases.

For a general test of the suitability of SEAP-APPswe fusion constructs as BACE1 reporters, HEK293 cells were used. Although of nonneuronal origin, HEK293 cells have been successfully applied in studies examining BACE1 overexpression and activity [58]. Furthermore, this cell type has been described as expressing APP in addition to functional $\alpha$-, $\beta$-, and $\gamma$-secretase activities allowing the sequential proteolytic processing of $A \beta[6,10,59,60]$. We corroborated these findings by our observation that overexpression of APPswe in HEK293 cells allowed A $\beta$ synthesis that was efficiently inhibited by the BACE1 inhibitors IPAD and AQD (Fig. 4B). Unfortunately, both inhibitors had only marginal effects on SEAP release. The reason for this finding is that the SEAP assay cannot distinguish between fusion proteins released by BACE1 activity 
and other proteins, only some longer amino acids released by $\alpha$-secretase activity. Such $\alpha$-secretase activity is very pronounced in HEK293 cells [10], but it also contributes to a significant amount of sAPP release in neuronal cells (Fig. 2). Inhibition of BACE1 further increased $\alpha$-secretase activity in neuronal cells, as indicated by higher amounts of SAPP $\alpha$ in the presence of a BACE1 inhibitor (Fig. 2B). The situation may be even more complicated under some assay conditions allowing for additional regulations of $\alpha$-secretase activities, for instance, by stimulation of protein kinase $C[61,62]$. In this context, it must be remembered that $\alpha$-secretase cleavage is not limited to a single protease but rather can be mediated by a variety of enzymes such as ADAM10, -11 , or -17 [63,64]. It is also noteworthy that BACE2, a close homologue of BACE1, comprises $\alpha$-secretase activity and, therefore, can prevent $A \beta$ formation. In our attempt to generate an exclusively BACE1-dependent assay system with SEAP as a functional readout, our first solution was the use of an APPwt overexpression construct carrying a point mutation in the $\alpha$-cleavage site (Fig. 5). Expression of this construct in HEK293 cells allowed the parallel detection of SEAP and A $\beta$ release into the medium and, therefore, permitted a direct comparison between the two assays (Fig. 6). The results (similar IC $\mathrm{C}_{50}$ values and strong BACE1 dependency) indicated that elimination of the $\alpha$-secretase cleavage site was basically the right approach. However, the overall assay window was limited by relatively poor BACE1 activity under these conditions. The assay showed relatively large standard deviations and worked optimally only when BACE1 was expressed ectopically in the same cells. Therefore, we looked for other possibilities to get rid of the $\alpha$-cleavage site. In addition, we sought to also eliminate the $\gamma$-cleavage site to make the assay absolutely monospecific for BACE1. In some other assay systems, $\gamma$-secretase inhibitors have been shown to modify $A \beta$ release $[65,66]$.

\section{A novel APP fusion protein allowing selective detection of BACE1 activity}

To avoid such complications altogether, a new APPswe construct was generated where the entire $\alpha$ - and $\gamma$-secretase cleavage sites were replaced by the transmembrane region of the EpoR. Use of this vector allowed the release of SEAP into the supernatant, which was strictly dependent on BACE1 activity (tested by inhibitors and siRNA), and allowed a highly sensitive assay. Residual activity of approximately $20 \%$ did not affect the assay sensitivity negatively and was not blocked by BACE1 inhibitors either by the additional use of the $\alpha$-secretase inhibitor GM6001 or by other unspecific inhibitors (not shown). The construct worked equally well in HEK293 cells and when introduced into neurons.

\section{Outlook}

These newly introduced models of APPswe fused with alkaline phosphatase as an alternative readout can be applied in various areas of $\mathrm{AD}$ research. For questions that depend on a typical neuronal architecture and that might involve the role of intracellular localization and trafficking, primary CGCs in combination with the SEAP-APPswe constructs and siRNA would be the cellular model of choice. For other questions that require higher throughput capacities (e.g., testing of novel potential BACE1 inhibitory compounds), the HEK293 model described in this work provides the advantages and complexity of a human cell system that allow an orchestrated processing of APP and might be a reproducible cost- and labor-efficient alternative for the assessment of BACE1 activity. An alternative field of application could be the testing of various siRNA libraries to identify enzymes or receptors that are involved in the regulation of BACE1 expression or localization.

\section{Acknowledgments}

We gratefully acknowledge the excellent work of A. Christiansen, N. Blatter and M. Gfell as well as the secretarial assistance of B. Schanze. This study was supported by $H$. Lundbeck A/S, the Doerenkamp-Zbinden Foundation, the Land Baden-Württemberg, and the DFG.

\section{References}

[1] P.D. Sloane, S. Zimmerman, C. Suchindran, P. Reed, L. Wang, M. Boustani, S. Sudha, The public health impact of Alzheimer's disease, 2000-2050: potential implication of treatment advances, Annu. Rev. Public Health 23 (2002) 213231.

[2] D.J. Selkoe, The molecular pathology of Alzheimer's disease, Neuron 6 (1991) $487-498$

[3] J. Hardy, D.J. Selkoe, The amyloid hypothesis of Alzheimer's disease: progress and problems on the road to therapeutics, Science 297 (2002) 353-356.

[4] M. Meyer-Luehmann, T.L. Spires-Jones, C. Prada, M. Garcia-Alloza, A. de Calignon, A. Rozkalne, J. Koenigsknecht-Talboo, D.M. Holtzman, B.J. Bacskai, B.T. Hyman, Rapid appearance and local toxicity of amyloid- $\beta$ plaques in a mouse model of Alzheimer's disease, Nature 451 (2008) 720-724.

[5] I. Hussain, D. Powell, D.R. Howlett, D.G. Tew, T.D. Meek, C. Chapman, IS. Gloger, K.E. Murphy, C.D. Southan, D.M. Ryan, T.S. Smith, D.L. Simmons, F.S. Walsh, C. Dingwall, G. Christie, Identification of a novel aspartic protease (Asp2) as $\beta$-secretase, Mol. Cell. Neurosci. 14 (1999) 419-427.

[6] R. Vassar, B.D. Bennett, S. Babu-Khan, S. Kahn, E.A. Mendiaz, P. Denis, D.B. Teplow, S. Ross, P. Amarante, R. Loeloff, Y. Luo, S. Fisher, J. Fuller, S. Edenson, J. Lile, M.A. Jarosinski, A.L. Biere, E. Curran, T. Burgess, J.-C. Louis, F. Collins, J. Treanor, G. Rogers, M. Citron, $\beta$-Secretase cleavage of Alzheimer's amyloid precursor protein by the transmembrane aspartic protease BACE, Science 286 (1999) 735-741.

[7] S. Sinha, J.P. Anderson, R. Barbour, G.S. Basi, R. Caccavello, D. Davis, M. Doan, H.F. Dovey, N. Frigon, J. Hong, K. Jacobson-Croak, N. Jewett, P. Keim, J. Knops, I. Lieberburg, M. Power, H. Tan, G. Tatsuno, J. Tung, D. Schenk, P. Seubert, S.M. Suomensaari, S. Wang, D. Walker, J. Zhao, L. McConlogue, V. John, Purification and cloning of amyloid precursor protein $\beta$-secretase from human brain, Nature 402 (1999) 537-540.

[8] R. Yan, M.J. Bienkowski, M.E. Shuck, H. Miao, M.C. Tory, A.M. Pauley, J.R. Brashler, N.C. Stratman, W.R. Mathews, A.E. Buhl, D.B. Carter, A.G. Tomasselli, L.A. Parodi, R.L. Heinrikson, M.E. Gurney, Membrane-anchored aspartyl protease with Alzheimer's disease $\beta$-secretase activity, Nature 402 (1999) 533-537.

[9] T. Müller, H.E. Meyer, R. Egensperger, K. Marcus, The amyloid precursor protein intracellular domain (AICD) as modulator of gene expression, apoptosis, and cytoskeletal dynamics: relevance for Alzheimer's disease, Prog. Neurobiol. 85 (2008) 393-406.

[10] F.S. Esch, P.S, Keim, E.C. Beattie, R.W. Blacher, A.R. Culwell, T. Oltersdorf, D. McClure, P.J. Ward, Cleavage of amyloid- $\beta$ peptide during constitutive processing of its precursor, Science 248 (1990) 1122-1124.

[11] F. Fahrenholz, R. Postina, $\alpha$-Secretase activation: an approach to Alzheimer's disease therapy, Neurodegen. Dis. 3 (2006) 255-261.

[12] G.T. Wong, D. Manfra, F.M. Poulet, Q. Zhang, H. Josien, T. Bara, L. Engstrom, M Pinzon-Ortiz, J.S. Fine, H.-J.J. Lee, L. Zhang, G.A. Higgins, E.M. Parker, Chronic treatment with the $\gamma$-secretase inhibitor LY-411, 575 inhibits $\beta$-amyloid peptide production and alters lymphopoiesis and intestinal cell differentiation, J. Biol. Chem. 279 (2004) 12876-12882.

[13] H. Cai, Y. Wang, D. McCarthy, H. Wen, D.R. Borchelt, D.L. Price, P.C. Wong BACE1 is the major $\beta$-secretase for generation of $A \beta$ peptides by neurons, Nat. Neurosci. 4 (2001) 233-234.

[14] Y. Luo, B. Bolon, S. Kahn, B.D. Bennett, S. Babu-Khan, P. Denis, W. Fan, H. Kha, J. Zhang, Y. Gong, L. Martin, J.-C. Louis, Q. Yan, W.G. Richards, M. Citron, R. Vassar, Mice deficient in BACE1, the Alzheimer's $\beta$-secretase, have normal phenotype and abolished $\beta$-amyloid generation, Nat. Neurosci. 4 (2001) 231232.

[15] S.L. Roberds, J. Anderson, G. Basi, M.J Bienkowski, D.G. Branstetter, K. S. Chen, S. Freedman, N.L. Frigon, D. Games, K. Hu, K. Johnson-Wood, K.E. Kappenman, T.T. Kawabe, I. Kola, R. Kuehn, M. Lee, W. Liu, R. Motter, N.F. Nichols, M. Power, D.W. Robertson, D. Schenk, M. Schoor, G.M. Shopp, M.E. Shuck, S. Sinha, K.A. Svensson, G. Tatsuno, H. Tintrup, J. Wijsman, S. Wright, L. McConlogue, BACE knockout mice are healthy despite lacking the primary $\beta$-secretase activity in brain: implications for Alzheimer's disease therapeutics, Hum. Mol. Genet. 10 (2001) 1317-1324

[16] D. Dominguez, J. Tournoy, D. Hartmann, T. Huth, K. Cryns, S. Deforce, L. Serneels, I.E. Camacho, E. Marjaux, K. Craessaerts, A.J.M. Roebroek, M. Schwake, R. D'Hooge, P. Bach, U. Kalinke, D. Moechars, C. Alzheimer, K. Reiss, P. Saftig, B. De Strooper, Phenotypic and biochemical analyses of BACE1- and BACE2-deficient mice, J. Biol. Chem. 280 (2005) 3079730806.

[17] M. Willem, A.N. Garratt, B. Novak, M. Citron, S, Kaufmann, A. Rittger, B. DeStrooper, P. Saftig C. Birchmeier, C. Haass, Control of peripheral nerve myelination by the $\beta$-secretase BACE1, Science 314 (2006) 664-666. 
[18] X. Hu, C.W. Hicks, W. He, P. Wong, W.B. Macklin, B.D. Trapp, R. Yan, Bace1 modulates myelination in the central and peripheral nervous system, Nat. Neurosci. 9 (2006) 1520-1525.

[19] Y. Luo, B. Bolon, M.A. Damore, D. Fitzpatrick, H. Liu, J. Zhang, Q. Yan, R. Vassar, M. Citron, BACE1 ( $\beta$-secretase) knockout mice do not acquire compensatory gene expression changes or develop neural lesions over time, Neurobiol. Dis. 14 (2003) 81-88.

[20] L. Hong, G. Koelsch, X. Lin, S. Wu, S. Terzyan, A.K. Ghosh, X.C. Zhang, J. Tang, Structure of the protease domain of memapsin 2 ( $\beta$-secretase) complexed with inhibitor, Science 290 (2000) 150-153.

[21] H. Shimizu, A. Tosaki, K. Kaneko, T. Hisano, T. Sakurai, N. Nukina, Crystal structure of an active form of BACE1, an enzyme responsible for amyloid $\beta$ protein production, Mol. Cell. Biol. 28 (2008) 3663-3671.

[22] C. Venugopal, C.M. Demos, K.S. Jagannatha Rao, M.A. Pappolla, K. Sambamurti, $\beta$-Secretase: structure, function, and evolution, CNS Neurol. Disorders Drug Targets 7 (2008) 278-294.

[23] C. Dash, A. Kulkarni, B. Dunn, M. Rao, Aspartic peptidase inhibitors: implications in drug development, Crit. Rev. Biochem. Mol. Biol. 38 (2003) 89-119.

[24] A.K. Ghosh, L. Hong, J. Tang, $\beta$-Secretase as a therapeutic target for inhibitor drugs, Curr. Med. Chem. 9 (2002) 1135-1144

[25] J. Walter, R. Fluhrer, B. Hartung, M. Willem, C. Kaether, A. Capell, S. Lammich, G. Multhaup, C. Haass, Phosphorylation regulates intracellular trafficking of $\beta$ secretase, J. Biol. Chem. 276 (2001) 14634-14641.

[26] S. Benjannet, A. Elagoz, L. Wickham, M. Mamarbachi, J.S. Munzer, A. Basak, C. Lazure, J.A. Cromlish, S. Sisodia, F. Checler, M. Chretien, N.G. Seidah, Posttranslational processing of $\beta$-secretase ( $\beta$-amyloid-converting enzyme) and its ectodomain shedding: the pro- and transmembrane/cytosolic domains affect its cellular activity and amyloid- $\beta$ production, J. Biol. Chem. 276 (2001) 10879-10887.

[27] J.T. Huse, D.S. Pijak, G.J. Leslie, V.M.Y. Lee, R.W. Doms, Maturation and endosomal targeting of $\beta$-site amyloid precursor protein-cleaving enzyme: the Alzheimer's disease $\beta$-secretase, J. Biol. Chem. 275 (2000) 33729-33737.

[28] D.R. Riddell, G. Christie, I. Hussain, C. Dingwall, Compartmentalization of $\beta$ secretase (Asp2) into low-buoyant density, noncaveolar lipid rafts, Curr. Biol. 11 (2001) 1288-1293.

[29] E.B. Lee, B. Zhang, K. Liu, E.A. Greenbaum, R.W. Doms, J.Q. Trojanowski, V.M.Y. Lee, BACE overexpression alters the subcellular processing of APP and inhibits A $\beta$ deposition in vivo, J. Cell Biol. 168 (2005) 291-302.

[30] G. Thinakaran, E.H. Koo, Amyloid precursor protein trafficking, processing, and function, J. Biol. Chem. 283 (2008) 29615-29619.

[31] S.J. Stachel, C.A. Coburn, T.G. Steele, K.G. Jones, E.F. Loutzenhiser, A.R. Gregro, H.A. Rajapakse, M.T. Lai, M.C. Crouthamel, M. Xu, K. Tugusheva, J.E. Lineberger, B.L. Pietrak, A.S. Espeseth, X.P. Shi, E. Chen-Dodson, M.K. Holloway, S. Munshi, A.J. Simon, L. Kuo, J.P. Vacca, Structure-based design of potent and selective cell-permeable inhibitors of human $\beta$-secretase (BACE-1), J. Med. Chem. 47 (2004) 6447-6450.

[32] E.W. Baxter, K.A. Conway, L. Kennis, F. Bischoff, M.H. Mercken, H.L. DeWinter, C.H. Reynolds, B.A. Tounge, C. Luo, M.K. Scott, Y. Huang, M. Braeken, S.M.A. Pieters, D.J.C. Berthelot, S. Masure, W.D. Bruinzeel, A.D. Jordan, M.H. Parker, R.E. Boyd, J. Qu, R.S. Alexander, D.E. Brenneman, A.B. Reitz, 2-Amino-3,4dihydroquinazolines as inhibitors of BACE-1 ( $\beta$-site APP cleaving enzyme): use of structure based design to convert a micromolar hit into a nanomolar lead, J. Med. Chem. 50 (2007) 4261-4264.

[33] H.F. Dovey, V. John, J.P. Anderson, L.Z. Chen, P. de Saint Andrieu, L.Y. Fang, S.B. Freedman, B. Folmer, E. Goldbach, Functional $\gamma$-secretase inhibitors reduce $\beta$ amyloid peptide levels in brain, J. Neurochem. 76 (2001) 173-181.

[34] D. Seiffert, J.D. Bradley, C.M. Rominger, D.H. Rominger, F. Yang, J.E. Meredith Jr., Q. Wang, A.H. Roach, L.A. Thompson, S.M. Spitz, J.N. Higaki, S.R. Prakash, A.P. Combs, R.A. Copeland, S.P. Arneric, P.R. Hartig, D.W. Robertson, B. Cordell, A.M. Stern, R.E. Olson, R. Zaczek, Presenilin-1 and -2 are molecular targets for $\gamma$ secretase inhibitors, J. Biol. Chem. 275 (2000) 34086-34091.

[35] I. Churcher, S. Williams, S. Kerrad, T. Harrison, J.L. Castro, M.S. Shearman, H.D. Lewis, E.E. Clarke, J.D.J. Wrigley, D. Beher, Y.S. Tang, W. Liu, Design and synthesis of highly potent benzodiazepine $\gamma$-secretase inhibitors: preparation of $(2 S, 3 R)$ 3-(3,4-difluorophenyl)-2-(4-fluorophenyl)-4-hydroxy- $N$-((3S)-1-methyl-2oxo-5-phenyl-2,3-dihydro-1H-benzo[ $e][1,4]$-diazepin-3-yl)butyramide by use of an asymmetric Ireland-Claisen rearrangement, J. Med. Chem. 46 (2003) 2275-2278

[36] B.D. Gitter, D.L. Czilli, W. Li, D.K. Dieckman, M.H. Bender, J.S. Nissen, T.E. Mabry, T. Yin, L.N. Boggs, D.B. McClure, S.P. Little, E.M. Johnstone, J.E. Audia, P.C. May, P.A. Hyslop, Stereoselective inhibition of amyloid $\beta$ peptide secretion by LY450139, a novel functional $\gamma$ secretase inhibitor, Neurobiol. Aging 25 (Suppl.2) (2004) S571 (Abstract P4-339).

[37] J.L. Jankowsky, D.J. Fadale, J. Anderson, G.M. Xu, V. Gonzales, N.A. Jenkins, N.G. Copeland, M.K. Lee, L.H. Younkin, S.L. Wagner, S.G. Younkin, D.R. Borchelt, Mutant presenilins specifically elevate the levels of the 42 residue $\beta$-amyloid peptide in vivo: evidence for augmentation of a 42-specific $\gamma$ secretase, Hum. Mol. Genet. 13 (2004) 159-170.

[38] J.L. Jankowsky, H.H. Slunt, T. Ratovitski, N.A. Jenkins, N.G. Copeland, D.R. Borchelt, Co-expression of multiple transgenes in mouse CNS: a comparison of strategies, Biomol. Eng. 17 (2001) 157-165.

[39] E. Hertz, A.C.H. Yu, L. Hertz, B.H.J. Juurlink, A. Schousboe, Preparation of primary cultures of mouse cortical neurons, in: A. Shahar, J. De Vellis, A. Vernadakis, B. Haber (Eds.), A Dissection and Tissue Culture Manual of the Nervous System, Alan R. Liss, New York, 1989, pp. 105-108.
[40] M. Leist, C. Volbracht, S. Kühnle, E. Fava, E. Ferrando-May, P. Nicotera, Caspasemediated apoptosis in neuronal excitotoxicity triggered by nitric oxide, Mol. Med. 3 (1997) 750-764

[41] C.L. Fisher, G.K. Pei, Modification of a PCR-based site-directed mutagenesis method, BioTechniques 23 (1997) 570-574.

[42] M. Leist, P. Ghezzi, G. Grasso, R. Bianchi, P. Villa, M. Fratelli, C. Savino, M. Bianchi, J. Nielsen, J. Gerwien, P. Kallunki, A.K. Larsen, L. Helboe, S. Christensen, L.O. Pedersen, M. Nielsen, L. Torup, T. Sager, A. Sfacteria, S. Erbayraktar, Z. Erbayraktar, N. Gokmen, O. Yilmaz, C. Cerami-Hand, Q.-W. Xie, T. Coleman, A. Cerami, M. Brines, Derivatives of erythropoietin that are tissue protective but not erythropoietic, Science 305 (2004) 239-242.

[43] J. Berger, J. Hauber, R. Hauber, R. Geiger, B.R. Cullen, Secreted placental alkaline phosphatase: a powerful new quantitative indicator of gene expression in eukaryotic cells, Gene 66 (1988) 1-10.

[44] E.J. King, A.R. Armstrong, A convenient method for determining serum and bile phosphatase activity, Can. Med. Assoc. J. 31 (1934) 376-381.

[45] K. Maruyama, F. Kametani, M. Usami, W. Yamao-Harigaya, K. Tanaka, "Secretase," Alzheimer amyloid protein precursor secreting enzyme is not sequence-specific, Biochem. Biophys. Res. Commun. 179 (1991) 1670-1676.

[46] S.S. Sisodia, $\beta$-Amyloid precursor protein cleavage by a membrane-bound protease, Proc. Natl. Acad. Sci. USA 89 (1992) 6075-6079.

[47] C. Haass, A.Y. Hung, D.J. Selkoe, D.B. Teplow, Mutations associated with a locus for familial Alzheimer's disease result in alternative processing of amyloid $\beta$ protein precursor, J. Biol. Chem. 269 (1994) 17741-17748.

[48] W. Zhang, D. Espinoza, V. Hines, M. Innis, P. Mehta, D.L. Miller, Characterization of $\beta$-amyloid peptide precursor processing by the yeast Yap3 and Mkc7 proteases, Biochim. Biophys. Acta 1359 (1997) 110-122.

[49] O. Middendorp, U. Lüthi, F. Hausch, A. Barberis, Searching for the most effective screening system to identify cell-active inhibitors of $\beta$-secretase, Biol. Chem. 385 (2004) 481.

[50] M. Oh, S.Y. Kim, Y.S. Oh, D.-Y. Choi, H.J. Sin, I.M. Jung, W.J. Park, Cell-based assay for $\beta$-secretase activity, Anal. Biochem. 323 (2003) 7-11.

[51] A.G. Tomasselli, I. Qahwash, T.L. Emmons, Y. Lu, J.W. Leone, J.M. Lull, K.F. Fok, C.A. Bannow, C.W. Smith, M.J. Bienkowski, R.L. Heinrikson, R. Yan, Employing a superior BACE1 cleavage sequence to probe cellular APP processing, J. Neurochem. 84 (2003) 1006-1017.

[52] B.L. Pietrak, M.-C. Crouthamel, K. Tugusheva, J.E. Lineberger, M. Xu, J.M. DiMuzio, T. Steele, A.S. Espeseth, S.J. Stachel, C.A. Coburn, S.L. Graham, J.P. Vacca, X.-P. Shi, A.J. Simon, D.J. Hazuda, M.-T. Lai, Biochemical and cell-based assays for characterization of BACE-1 inhibitors, Anal. Biochem. 342 (2005) $144-151$.

[53] M. Citron, T. Oltersdorf, C. Haass, L. McConlogue, A.Y. Hung, P. Seubert, C. VigoPelfrey, I. Lieberburg, D.J. Selkoe, Mutation of the $\beta$-amyloid precursor protein in familial Alzheimer's disease increases $\beta$-protein production, Nature 360 (1992) 672-674.

[54] A. Jan, O. Gokce, R. Luthi-Carter, H.A. Lashuel, The ratio of monomeric to aggregated forms of $A \beta 40$ and $A \beta 42$ is an important determinant of $A \beta$ aggregation, fibrillogenesis, and toxicity, J. Biol. Chem. 283 (2008) 2817628189.

[55] X.D. Cai, T.E. Golde, S.G. Younkin, Release of excess amyloid $\beta$ protein from a mutant amyloid $\beta$ protein precursor, Science 259 (1993) 514-516.

[56] F. Mancini, M. Naldi, V. Cavrini, V. Andrisano, Multiwell fluorometric and colorimetric microassays for the evaluation of $\beta$-secretase (BACE- 1 ) inhibitors, Anal. Bioanal. Chem. 388 (2007) 1175-1183.

[57] S.F. Lichtenthaler, Ectodomain shedding of the amyloid precursor prote, in: cellular control mechanisms and novel modifiers, Neurodegen. Dis. 3 (2006) 262-269.

[58] D. Andrau, C. Dumanchin-Njock, E. Ayral, J. Vizzavona, M. Farzan, M. Boisbrun, P. Fulcrand, J.-F. Hernandez, J. Martinez, S. Lefranc-Jullien, F. Checler, BACE1and BACE2-expressing human cells: characterization of $\beta$-amyloid precursor protein-derived catabolites, design of a novel fluorimetric assay, and identification of new in vitro inhibitors, J. Biol. Chem. 278 (2003) 2585925866.

[59] C. Haass, M.G. Schlossmacher, A.Y. Hung, C. Vigo-Pelfrey, A. Mellon, B.L. Ostaszewski, I. Lieberburg, E.H. Koo, D. Schenk, D.B. Teplow, D.J. Selkoe, Amyloid $\beta$-peptide is produced by cultured cells during normal metabolism, Nature 359 (1992) 322-325.

[60] D. Edbauer, E. Winkler, C. Haass, H. Steiner, Presenilin and nicastrin regulate each other and determine amyloid $\beta$-peptide production via complex formation, Proc. Natl. Acad. Sci. USA 99 (2002) 8666-8671.

[61] J.D. Buxbaum, S.E. Gandy, P. Cicchetti, M.E. Ehrlich, A.J. Czernik, R.P. Fracasso, T.V. Ramabhadran, A.J. Unterbeck, P. Greengard, Processing of Alzheimer $\beta / A 4$ amyloid precursor prote, in: modulation by agents that regulate protein phosphorylation, Proc. Natl. Acad. Sci. USA 87 (1990) 6003-6006.

[62] S. Roßner, M. Beck, T. Stahl, K. Mendla, R. Schliebs, V. Bigl, Constitutive overactivation of protein kinase $C$ in guinea pig brain increases $\alpha$-secretory APP processing without decreasing $\beta$-amyloid generation, Eur. J. Neurosci. 12 (2000) 3191-3200.

[63] M.L. Moss, S.L.C. Jin, M.E. Milla, W. Burkhart, H.L. Carter, W.-J. Chen, W.C. Clay, J.R. Didsbury, D. Hassler, C.R. Hoffman, T.A. Kost, M.H. Lambert, M.A. Leesnitzer, P. McCauley, G. McGeehan, J. Mitchell, M. Moyer, G. Pahel, W. Rocque, L.K. Overton, F. Schoenen, T. Seaton, J.-L. Su, J. Warner, D. Willard, J.D. Becherer, Cloning of a disintegrin metalloproteinase that processes precursor tumour-necrosis factor- $\alpha$, Nature 385 (1997) 733-736.

[64] S. Lammich, E. Kojro, R. Postina, S. Gilbert, R. Pfeiffer, M. Jasionowski, C. Haass, F. Fahrenholz, Constitutive and regulated $\alpha$-secretase cleavage of Alzheimer's 
amyloid precursor protein by a disintegrin metalloprotease, Proc. Natl. Acad. Sci. USA 96 (1999) 3922-3927.

[65] T.A. Lanz, M.J. Karmilowicz, K.M. Wood, N. Pozdnyakov, P. Du, M.A. Piotrowski, T.M. Brown, C.E. Nolan, K.E.G. Richter, J.E. Finley, Q. Fei, C.F. Ebbinghaus, Y.L Chen, D.K. Spracklin, B. Tate, K.F. Geoghegan, L.-F. Lau, D.D. Auperin, J.B. Schachter, Concentration-dependent modulation of amyloid- $\beta$ in vivo and in vitro using the $\gamma$-secretase inhibitor, LY-450139, J. Pharmacol. Exp. Ther. 319 (2006) 924-933.
[66] C.R. Burton, J.E. Meredith, D.M. Barten, M.E. Goldstein, C.M. Krause, C.J. Kieras, L. Sisk, L.G. Iben, C. Polson, M.W. Thompson, X.-A. Lin, J. Corsa, T. Fiedler, M. Pierdomenico, Y. Cao, A.H. Roach, J.L. Cantone, M.J. Ford, D.M. Drexler, R.E. Olson, M.G. Yang, C.P. Bergstrom, K.E. McElhone, J.J. Bronson, J.E. Macor, Y. Blat, R.H. Grafstrom, A.M. Stern, D.A. Seiffert, R. Zaczek, C.F. Albright, J.H. Toyn, The amyloid- $\beta$ rise and $\gamma$-secretase inhibitor potency depend on the level of substrate expression, J. Biol. Chem. 283 (2008) 22992-23003. 